\title{
The Impact of Mergers and Acquisitions and Sustainability on Company Performance in the Pharmaceutical Sector
}

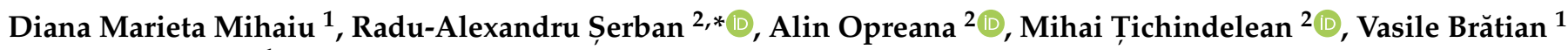 \\ and Liliana Barbu ${ }^{1}$ \\ 1 Department of Finance and Accounting, Lucian Blaga University of Sibiu, 550024 Sibiu, Romania; \\ diana.mihaiu@ulbsibiu.ro (D.M.M.); vasile.bratian@ulbsibiu.ro (V.B.); liliana.barbu@ulbsibiu.ro (L.B.) \\ 2 Department of Management, Marketing and Business Administration, Lucian Blaga University of Sibiu, \\ 550024 Sibiu, Romania; alin.opreana@ulbsibiu.ro (A.O.); mihai.tichindelean@ulbsibiu.ro (M.T.) \\ * Correspondence: radu.serban@ulbsibiu.ro
}

check for updates

Citation: Mihaiu, D.M.; Șerban, R.-A.; Opreana, A.; Tichindelean, M.; Brătian, V.; Barbu, L. The Impact of Mergers and Acquisitions and Sustainability on Company Performance in the Pharmaceutical Sector. Sustainability 2021, 13, 6525. https://doi.org/10.3390/su13126525

Academic Editors:

José-Luis Rodríguez-Sánchez and Fernando Enrique García-Muiña

Received: 30 April 2021

Accepted: 6 June 2021

Published: 8 June 2021

Publisher's Note: MDPI stays neutral with regard to jurisdictional claims in published maps and institutional affiliations.

Copyright: (c) 2021 by the authors. Licensee MDPI, Basel, Switzerland. This article is an open access article distributed under the terms and conditions of the Creative Commons Attribution (CC BY) license (https:// creativecommons.org/licenses/by/ $4.0 /)$.

\begin{abstract}
The primary goal of this study was to determine the impact of mergers and acquisitions (M\&A) and the environmental, social, and governance (ESG) sustainability scores of companies. In this regard, efforts to measure and analyze the evolution of a company's performance, taking into account financial and non-financial measures using a score function, are adapted to the pharmaceutical sector. The sample consisted of 100 leading pharmaceutical companies, ranked by stock market capitalization, who registered 30\% $(n=492)$ of the total M\&A transactions over the study period (2010-2020). There was a direct and positive link between the M\&A process and the evolution of company performance. The ESG score, as an indicator for measuring sustainability, has a positive and direct impact on company performance, indicating that a high ESG score determines an increase in company performance. A similar impact is identified for companies involved in M\&A processes, meaning that companies in the pharmaceutical sector tend to register a performance improvement.
\end{abstract}

Keywords: M\&A; sustainability; company performance; performance score; pharmaceutical sector

\section{Introduction}

Merger and acquisition transactions represent strategic decisions that add up to significant values worldwide, both in terms of the number of transactions performed and their value. Analyzing the sectors of activity, we found an accentuated tendency of companies in the pharmaceutical sector towards such development strategies. The major objectives of these transactions include strengthening operations, expanding presence in primary/secondary markets, expanding presence in new geographical regions, creating synergies, eliminating duplicate services, increasing shareholder value, taking advantage of sound investment opportunities, offering new products and services, acquiring the technological/strategic assets of competitors, and benefiting from fiscal advantages.

The ultimate goal of these objectives is to improve the performance of companies that have gone through such merger and acquisition transactions. Company performance has both financial and non-financial dimensions.

The objective of our paper is to analyze the impact of mergers and acquisitions (M\&A) and sustainability on the evolution of corporate performance in the pharmaceutical sector. During the study period (2011-2020), there were 1663 M\&A transactions completed in the pharmaceutical sector, according to TRBC (The Refinitiv Business Classification). The sample study consisted of 100 companies at the top of the pharmaceutical sector, ranked by stock market capitalization, who registered a total of $492 \mathrm{M} \& \mathrm{~A}$ transactions in the analyzed period ( $30 \%$ of the total complete transactions).

To quantify the financial dimension of company performance, we used ratio analysis based on financial statements for the 2011-2020 period; the ESG score for the same 
time frame, calculated by Refinitiv, was used to assess the non-financial dimension of performance, aimed at the sustainable development of the company.

The paper aims (a) to measure the company's performance, considering the financial and non-financial dimensions by using a Z-score function adapted to the particularities of the pharmaceutical sector, and (b) to determine the impact of M\&A transactions and the ESG sustainability score on the evolution of company performance.

Several studies have analyzed the impact of M\&A transactions based on company financial performance and the generated financial synergies. First, this exploratory study aims to contribute to the current M\&A literature by analyzing the impact of M\&A transactions and sustainability on company performance evolution. Second, the performance measurement approach takes into account not only the financial dimension but also the non-financial dimension of the performance. Third, in addition to previous research, this study takes into consideration an entire sector of activity (i.e., the pharmaceutical sector) globally, without any regional limitations.

To achieve this goal, we structured this paper as follows: The 'Literature Review' section reflects the results of studies carried out on the two topics approached (M\&A and sustainability); the section entitled 'Materials and Methods' presents the methodology used to determine the Z-score function to measure the company performance and the data used in the analysis; the 'Results' section presents the performance scores of the companies in the analyzed sample; and, finally, the paper ends with the 'Discussion and Conclusions' section, which is dedicated to detailing the impact of the two dimensions analyzed on the evolution of company performance, the limits of the study, and future research directions.

\section{Literature Review}

\subsection{Mergers and Acquisitions-Between Success and Failure}

The development strategy of a company is very important to lead the company to success. To this end, companies can choose between internal growth, through continuous improvement and optimization of operational and financial assets; external growth, through mergers and acquisitions, as well as strategic alliances (i.e., joint ventures) with other companies; or a combination of internal and external growth strategies. Mergers and acquisitions (M\&A) are one of the most-used strategies for the external growth and development of companies. The area of M\&A has been intensively researched, but from different and fragmented perspectives, with an emphasis on the link between M\&A and financial variables, and with less analysis of the impact of non-financial variables on transaction success [1]. Therefore, the objective of our study is to analyze the impacts of M\&A, both on financial variables and non-financial variables, which determine the level of sustainability of companies.

The volume of business transactions reached a maximum value of USD 4920 million with 47,455 transactions in 2007, while there was a maximum number of 52,740 transactions worldwide in 2017, totaling a value of USD 3776 million. In 2020, against the background of the global financial instability generated by the COVID-19 pandemic, transactions with companies registered a downward trend, compared to 2019: the volume of transactions decreased by approximately 16\%, registering a value of USD 2835 million, while the number of transactions decreased by about $7.5 \%$, recording a value of 45,652 transactions [2]. Although M\&A transactions are an important strategy for corporate restructuring, according to recent studies, their failure rate is quite high - between $40 \%$ and $90 \%$ of total transactions - with some studies highlighting even more restrictive ranges (e.g., 70-90\% failure rate) [3-9].

Transactions with companies are determined by various motivations, but the main objective of these transactions is to obtain financial synergies by increasing the efficiency and improving the financing activities of the company (i.e., tax, profitability, and debt capacity). The willingness to participate in such transactions is influenced by objective factors (e.g., market expansion, tax advantages, access to valuable resources, cost reductions), as well as by subjective factors, such as the desires of the management and the personalities of the 
CEO and CFO [10]. The relationship between the personality features of CEOs and CFOs and the propensity toward M\&A has also been studied, which has created a profile with the greatest openness to such transactions [11].

Although expectations from such transactions are favorable, this has been achieved in few cases. Moreover, in most transactions, a deterioration of the situation of companies involved in M\&A is observed. However, even if the performance objectives are not always reached in the case of companies directly involved in the transaction, studies have shown that competitors suffer as a result of M\&A, especially in the high-tech sector [12].

\subsection{The Impact of MEA on Company Performance}

The impact of M\&A on company performance due to these transactions is another topic of interest. Research conducted in this direction has generated results that reflect either a positive impact of M\&A on the company performance after the M\&A or a negative or mixed impact (on various dimensions of performance).

A study conducted on high-tech industries (including the pharmaceutical industry) has revealed that non-technological M\&A did not improve the performance of the resulting company; to the contrary, it decreased its performance. On the other hand, technological M\&A enables companies to better realize synergies, but cannot guarantee success in any case, as influenced by the ability to integrate the acquired innovative activities [13]. However, it has been noted that M\&A transactions can generate an increase in technological performance in high-tech industries if they were based on the acquisition and integration of research-intensive companies [14].

Analyzing M\&A transactions in the Chinese and US pharmaceutical industries between 2008 and 2016, it has been found that M\&A transactions aimed at expanding the value chain and at the latest technological acquisitions had a positive influence on company performance in the Chinese pharmaceutical industry and a negative influence in the US pharmaceutical industry [15]. From these studies, it can be deduced that the success of M\&A transactions is not specific to a certain sector of activity, but it also depends on the degree of state intervention in the economy, due to certain differences between the US and Chinese economies.

Looking at M\&A transactions separately, studies have shown that the acquisition transactions generated significant increases in profitability for the acquiring company, both in the short- and long-term; however, merger transactions, although much preferred by investors, have not generated obvious increases in profitability [16]. Another global study that analyzed the pharmaceutical sector identified that large companies which had entered into a merger "experienced slower operating profit growth in the third year after the merger", and the small companies that merged "experienced relatively slow growth of R\&D in the first year compared to similar firms that did not merge, suggesting that postmerger integration may absorb the cash that is necessary to finance R\&D" [17]. Therefore, the resulting synergistic effects have a short-term effect, decreasing in intensity in the medium- and long-term.

Regarding the banking sector, the impact of the M\&A transactions upon THE postM\&A performance of banks is uncertain, as some financial indicators recorded increases (but not in all cases), while other indicators, such as profitability, recorded decreases [18].

The analysis of various sectors showed that it is not possible to formulate a general conclusion regarding the favorable impact of M\&A on company performance; however, a favorable impact has been observed in the high-tech sector, while mixed results have been noticed in other sectors, such as banking and pharmaceutics.

Moreover, another study conducted on M\&A, regardless of the sector, in ASEAN countries has demonstrated that operational performance (quantified by return on assets) deteriorates over the three years following M\&A [7]. Other studies have also shown that total asset turnover based on sales did not show significant post-M\&A improvements but, in some cases, "the long-term operating cash flow ratio based on sales of the acquiring firms have improved" $[19,20]$. Another large-scale study of M\&A transactions in Europe and the 
UK has shown that the operational performance of companies involved in the transactions was superior to the sector averages before the moment of the transaction; then, after the transaction was carried out, it was not possible to draw a generalized conclusion concerning the unfolding of the post-M\&A operational performance but, instead, it was influenced by the specific characteristics of the transaction (e.g., friendly vs. hostile, domestic vs. across the border, and so on) [21]. In the case of 138 mergers in Europe and the US, a deterioration of the return on the sales ratio in the post-merger period has been observed [22]. The way that the M\&A transaction is financed also influences its success; a study has shown that M\&A transactions financed by equity performed much better than loan-financed transactions [23]. Another aspect is the geographical location of the companies involved, which can have a positive impact on the success of M\&A through cost advantage and differentiation strategies [24]; at the same time, more attention must be paid to cultural differences, which can nullify these potential financial benefits if cultural integration issues are neglected $[25,26]$. Cultural integration is very important in the success of an M\&A transaction. However, this aspect is often neglected, a fact noticed in the post-M\&A integration process where cultural integration plans are missing. Not least, according to some studies, domestic M\&A typically has superior performance to cross-border M\&A companies $[27,28]$.

The impact of M\&A on company performance is not only related to the sector of the companies involved or their geographical location. The profitability rate has been found to be higher in the case of companies that increased through internal growth strategies, compared to those that increased through external growth strategies; namely, through acquisitions of companies [29].

From the analysis of the bibliographic sources mentioned above, it was not possible to identify, with certainty, the favorable or unfavorable impact of M\&A on the resulting companies, with the opinions remaining divided in this regard. As a result, company managers cannot rely on the fact that the simple decision to engage in an M\&A transaction will guarantee their business success and increased profitability; it requires a well-grounded and comprehensive strategy, as well as a lot of work, to integrate and benefit from the potential business advantages.

\subsection{Measuring Post-MEA Financial Performance}

The outcome of an M\&A transaction depends directly on how well the success of the transaction is defined. In general, an M\&A transaction is considered successful if it generates an increase in the financial performance of the resulting company. The measurement of financial performance, in general, and the post-M\&A performance, in particular, does not have a commonly accepted methodology; hence, a series of questions arise, including: How should post-M\&A financial performance be defined for a company; what methodology should be used to measure post-M\&A financial performance; and what time horizon should be considered [30,31]? Another aspect to consider is whether the success of an M\&A transaction relies only on the improvement of financial parameters, or if other parameters should also be considered, such as those related to the company's sustainability [32]. The financial performance of a company is influenced by numerous factors, including corporate governance, ownership structure, and the size of the company [33]. Numerous studies have also shown that corporate sustainability favorably influences the financial performance of a company [34-36]. However, not all studies have supported this favorable aspect; to the contrary, various studies have supported the idea that corporate social performance negatively impacts financial performance [37].

Measuring a company's financial performance can take various forms, from developing sets of financial indicators to using the company's value (i.e., company book value or market value) to evaluate financial performance [38]. In general, the most-used methods for measuring the financial performance of a company are through accounting-based indicators, market-based indicators, or mixed methods [39-41]. 
A bibliographic analysis of the impact of M\&A on the company performance has identified four categories of studies using different methods for measuring post-M\&A financial performance, summarizing them as follows: "marked measures-based studies, accounting measures-based studies, mixed measures-based studies, and qualitative measures-based studies" [42]. Another bibliographic study has identified nine methods used to measure post-M\&A performance: event studies, accounting return, economic value-added, residual income approach, Questionnaire Method, Data Envelopment Analysis, Innovative Performance, Case Study Approach, and Studies using Multiple Methodologies (balanced scorecard approach), while those most used by researchers in their studies were event studies and accounting return [43].

To measure the financial performance of the company, we chose to apply financial ratio analysis, based on 22 ratios grouped into four categories: profitability, market value, assets and debt management, and liquidity and solvency. As further described in the methodology section, the Z-score function assesses only the ratios with the highest parameters of importance.

\subsection{Measuring the Sustainability of the Company}

A recent bibliographic study on sustainability research in M\&A has highlighted the fact that research on performance measurement went beyond traditional financial indicators, by integrating the three pillars of sustainability [44].

Sustainability for companies focuses on meeting short- and medium-term goals without compromising the ability to achieve long-term goals. The concept of sustainability is built on three pillars: economic, social, and environmental, known informally as profits, people, and the planet [45]. In order to be sustainable, companies need to address economic issues, as well as social issues, business ethics, and environmental justice [46].

In the specialized literature, a common ground has been found with respect to the concept of sustainability (i.e., the adoption of the three pillars of sustainability), but there are still debates regarding its measurement and the existing methodologies still differ. Generally, to measure the sustainability of a company, composite indicators are used, which take into account sub-indicators on each dimension of sustainability. The most well-known methodologies for measuring sustainability are the Environmental Social and Governance (ESG) framework, Corporate Social Responsibility (CSR), and Creating Shared Value (CSV). These concepts have in common the fact that all are attempting to define proper and standard sustainable behavior which includes all financial and non-financial elements. ESG has increased in popularity among investors and financial analysts and become an important factor in describing the performance of a company in the environmental, social, and governance areas [47]. ESG is used as an evaluation tool by investors and the capital markets and is related to sustainable investing, socially responsible investing, and corporate behavior. Based on these criteria, it evaluates the future performance of a company using either a score (i.e., between 10 and 100) or a rating (i.e., between D- and A+). Moreover, the ESG analysis can reveal the long-term perspective of a company, where benchmarking the ESG score or rating against competitors or industries can provide valuable decision-making information for investors, regarding the company's management processes, the quality of the board, governance practices, sustainable investments, and so on. Compared to the Socially Responsible Investment (SRI) concept, the ESG has increased in popularity, based on a 2005 study entitled "Who Cares Wins" [48]. Since the beginning, the main contribution of ESG was its proposition to cover factors that are not traditionally considered in financial analyses, but which could have a financial impact. Even though SRI has been around for a much longer period of time, ESG grew in popularity more rapidly, as the factors analyzed in ESG have a financial impact; compared with SRI, which is related to ethical and moral behavior aspects, such as not investing in certain industries (e.g., tobacco and alcohol).

The study "Who Cares Wins," together with the "Freshfield Report" released by the UNEP FI, which highlighted the fact that ESG is linked with financial evaluation, were the 
cornerstone for the release of the Principles for Responsible Investment (PRI; 2005) and the launch of the Sustainable Stock Exchange Initiative (SSEI; 2006).

Even though ESG has risen in popularity, growing into the mainstream at a very fast pace, there have been several challenges, some of which remain unsolved. One of the first issues was getting investors to embrace the concept, biased by the idea that their duty was to maximize shareholder value, while focusing on environmental, social, and governance issues could limit their objective. This concern was surpassed almost entirely when evidence showed the financial implications of ESG issues. Other concerns are related to the lack of standardized tools, data, disclosure, and reporting of ESG issues. The Global Reporting Initiative (GRI) has made significant progress in this regard, with almost $80 \%$ of the world's largest companies now using GRI standards. Moreover, for reporting in a specific industry or sector, the International Integrated Reporting Initiative (IIRC) and the Sustainability Accounting Standard Board (SASB) have been working on solutions in this regard. Significant progress has been made toward ESG reporting, but it is still a work in progress. ESG measurements have been made by third-party organizations and investment managers, as well as financial and public institutions, researchers, and various stakeholders, who use the ESG results to compare the performance of their organization with that of its peers. Several authors [49-51] and various publications [52,53] have agreed upon the fact that, at present, there are a dozen third-party ESG service providers. They have also agreed upon the fact that each one of them uses different methodologies, rating scales, and metrics. This means there will be very different results for a company measuring the same indicator (i.e., ESG performance) from different sources. Even if various companies provide ESG services, the market is dominated by a few companies, such as MSCI ESG Research, Sustainalytics Company ESG Reports, Bloomberg ESG Data Service, Thomson Reuters ESG Research Data, RepRisk, DowJones Sustainability Index (DJSI), Corporate Knights Global 100, and Institutional Shareholder Services (ISS) as a new entrant, but with great influence on their ESG services.

A recent meta-analysis [54], which combined the results of approximately 2200 studies, showed that much of the work has reported a positive relationship between ESG score/rating and financial performance.

\section{Materials and Methods}

To understand and appreciate the financial standing of a company, numerous models have been developed, such as the DuPont Model, Balanced Scorecards, Organizational Development Pyramid, Zeta Model, The Performance Prism, and so on. After the 1980s, emphasis was placed on what to measure and how performance indicators help in strategic alignment, with various performance measurement models being developed to synchronize performance indicators with business strategy [55]. Several publications have focused on this topic and developed conventional prediction models over the past 50 years [56-59]. The number of models has increased enormously, due to the increasing availability of data and the development of improved econometric techniques in the 1980s and 1990s.

The score function is widely used as a system to measure the financial standing of a company. Scoring methods can be grouped into two categories: statistical models and models based on artificial intelligence. The first category includes the Logit model, multivariate discriminatory analysis, and so on. The tool used to calculate the score was the univariate data analysis model proposed by Beaver [60], followed by the multivariate discriminant analysis and regressions proposed by Ohlson [61]. Z-scores reveal to analysts and investors whether a score is typical for a specified data set, or if it is atypical. Z-scores also make it possible for analysts and investors to adapt scores to get a better idea of how good or bad a score is, relative to the entire group.

The company performance was measured by considering the financial and nonfinancial performance dimensions. For the financial performance dimension, a quantitative analysis was applied, based on financial ratios grouped into four categories [62] Profitability, Liquidity and Solvency, Assets and Debt Management, and Market Value (see 
Figure 1)—using data gathered from the financial statements of sample companies from the pharmaceutical sector. For the non-financial performance dimension, the ESG score was considered as a measure of sustainability. The ESG score was calculated by Refinitiv to measure the relative ESG performance of companies, covering 10 main themes [63]. The financial ratios from the categories described above were selected, based on the parameter of importance (see methodology below), and introduced into a Z-score function. The results of the Z-score function were normalized (see methodology below), in order to obtain a score between 10 and 100 , where 10 is the lowest score and 100 the best score, as a measurement of company performance, and the comparison between companies in the sector was analyzed.

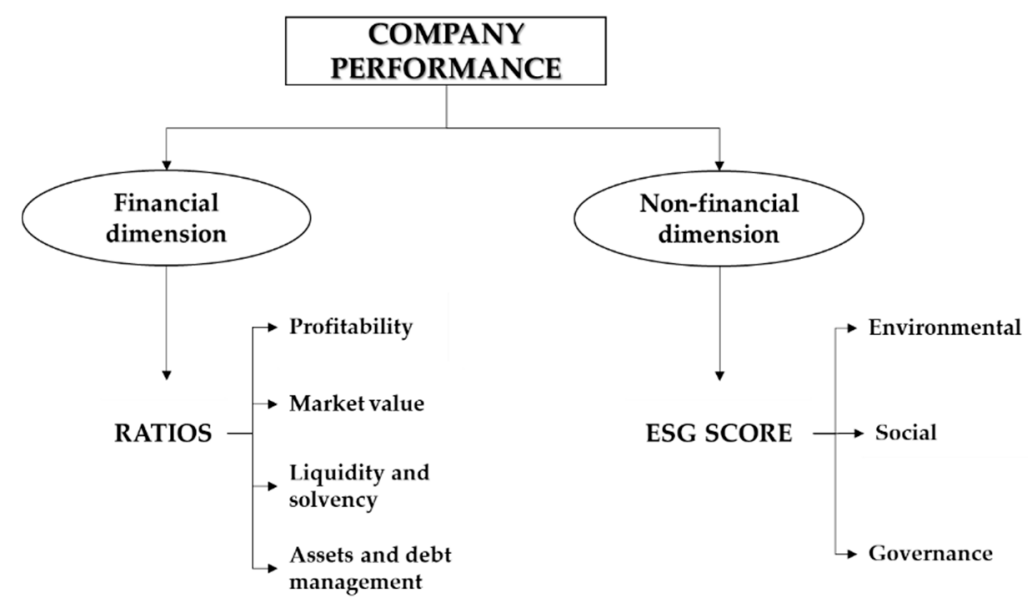

Figure 1. Representation of the indicators selected for company performance measurement. Source: Author's representation, based on Brigham, Eugene F., and Joel F. Houston's classification p. 107, 2019.

\subsection{Sample Study Description}

The sample companies $(n=100)$ in this study were classified according to TRBC (The Refinitiv Business Classification) in the Business Sector-pharmaceuticals and medical research, Industry Group, and Industry - pharmaceuticals. This classification is a comprehensive, detailed, and up-to-date sector and industry classification, which enabled benchmark analysis and peer comparison in our study sample [64].

For sampling, the following equation was used [65]:

$$
\mathrm{n}=\frac{\mathrm{t}^{2} \times \mathrm{p} \times \mathrm{q}}{\mathrm{e}^{2}}
$$

where:

$\mathrm{n}=$ the sample size;

$\mathrm{t}=$ the $\mathrm{t}$-value;

$\mathrm{p}=$ the non-percentage share of the components of the sample that are characterized by a certain attribute;

$q=$ the non-percentage share of the sample components that are not characterized by a certain attribute is determined as 1-p;

$\mathrm{e}=$ the margin of error.

Based on Equation (1), with a confidence level of $90 \%$ (degree of significance, 0.1 ), a tvalue of 1.65 , and an e value of 0.075612 , according to the criterion of at least one completed M\&A transaction $(p=0.3$, meaning that $30 \%$ of the companies from the pharmaceutical sector had registered at least one completed M\&A transaction in the period analyzed, 2010-2020; see Table 1), and $q=0.7$, we obtained a sample of 100 companies. 
Table 1. Complete M\&A transactions: total companies vs. 100 sample companies in the pharmaceutical sector (2010-2020).

\begin{tabular}{|c|c|c|c|c|c|c|c|c|}
\hline Transactions & Merger & $\begin{array}{l}\text { Acquisition } \\
\text { of Assets }\end{array}$ & $\begin{array}{l}\text { Acquisition of } \\
\text { Remaining } \\
\text { Interest }\end{array}$ & Buyback & $\begin{array}{l}\text { Acquisition } \\
\text { of Majority } \\
\text { Assets }\end{array}$ & $\begin{array}{l}\text { Acquisition } \\
\text { of Partial } \\
\text { Interest }\end{array}$ & $\begin{array}{c}\text { Exchange } \\
\text { Offer }\end{array}$ & $\begin{array}{c}\text { Acquisition } \\
\text { of Certain } \\
\text { Assets }\end{array}$ \\
\hline $\begin{array}{c}1663 \text { complete } \\
\text { transactions }\end{array}$ & 570 & 582 & 47 & 56 & 191 & 197 & 9 & 11 \\
\hline $\begin{array}{l}492 \text { complete } \\
\text { transactions }\end{array}$ & 192 & 154 & 13 & 19 & 41 & 70 & 2 & 1 \\
\hline $\begin{array}{l}\text { (\%) sample from } \\
\text { total }\end{array}$ & $34 \%$ & $26 \%$ & $28 \%$ & $34 \%$ & $21 \%$ & $36 \%$ & $22 \%$ & $9 \%$ \\
\hline
\end{tabular}

Source: Author's computation in Excel, based on Refinitiv Eikon M\&A transactions database.

\subsection{Determining the Z-Score Function}

Starting from the linear function we can build the Zeta mathematical model:

$$
\begin{gathered}
f(x)=a \times x+b, \\
Z=a_{1} \times X_{1}+a_{2} \times X_{2}+a_{3} \times X_{3}+\ldots+a_{n} \times X_{n}+\sum b,
\end{gathered}
$$

where $a_{1} \ldots a_{n}$ and $b$ represent the parameters for the variables $X_{1} \ldots X_{n}$, which are calculated depending on how variables can be optimized by maximizing or minimizing. The optimization of the variables $X$ depends on the objective of the financial ratio used (i.e., for the profits, we need to maximize, while for the costs we need to minimize).

For the variables which are optimized by maximizing, the $a$ and $b$ parameters are calculated as follows:

$$
\mathrm{a}=\frac{1}{\mathrm{X}_{\max }-\mathrm{X}_{\min }} ; \mathrm{b}=\frac{-\mathrm{X}_{\min }}{\mathrm{X}_{\max }-\mathrm{X}_{\min }}
$$

For the variables which are optimized by minimizing, the $\mathrm{a}$ and $\mathrm{b}$ parameters are calculated as follows:

$$
\mathrm{a}=\frac{1}{\mathrm{X}_{\min }-\mathrm{X}_{\max }} ; \mathrm{b}=\frac{-\mathrm{X}_{\max }}{\mathrm{X}_{\min }-\mathrm{X}_{\max }}
$$

After calculating the parameters, a and $b$ for each variable, the extreme values (or outliers) were excluded from the data set by computing the values of each variable in IBM SPSS and calculating the standard deviation. The values of the variables that exceeded \pm three Std. Dev. (standard deviations) were excluded from the data set.

\subsection{Z-Score Function Data Normalization}

The results of the Z-score function have been normalized using the formula below, so fall into the range [10,100]. The normalization formula was adapted from that used by the World Economic Forum for their Competitiveness Index:

$$
Z_{i j}=90 \times \frac{Z_{i j}-Z_{i m i n}}{Z_{\text {imax }}-Z_{\text {imin }}}+10,
$$

where:

$Z_{i j}=$ the calculated value of the $Z$-score $i$ for company $j$;

$Z_{\text {imax }}=$ the maximum value of the Z-score $i$ function; and

$Z_{\text {imin }}=$ the minimum value of the $Z$-score $i$ function.

The scores obtained by applying the Z-score function and the normalization process enabled us to have results in the range between 10 and 100, where 10 is the lowest performance score and 100 is the best performance score. An average growth index was calculated for the period analyzed, as follows:

$$
\begin{gathered}
\text { Annual growth index }=\frac{\text { Value this year }}{\text { Value in the previous year }}, \\
\text { Average growth index }=\sqrt[n]{\prod \text { Annual growth indices, }}
\end{gathered}
$$


where $\mathrm{n}$ is the number of annual growth indices calculated.

\section{Results}

The data set consisted of 100 companies from the pharmaceutical sector, analyzed for a period of 10 years (2011-2020). All of the companies had been involved in at least one M\&A form of transaction between 2010 and 2020. We took into consideration the year 2010, such that we would be able to see the results of the M\&A process in the following financial year.

Financial ratios were calculated for the entire sample $(n=100)$ in the period analyzed, depending on the availability of the data. Then, applying the methodology described above, we optimized each variable and calculated the Std. Dev. in IBM SPSS, in order to exclude the extreme variables (outliers); see Figure 2 and Appendix A. The variables were then ranked according to the parameters of importance $a$ and $b$; the results are shown in Table 2.

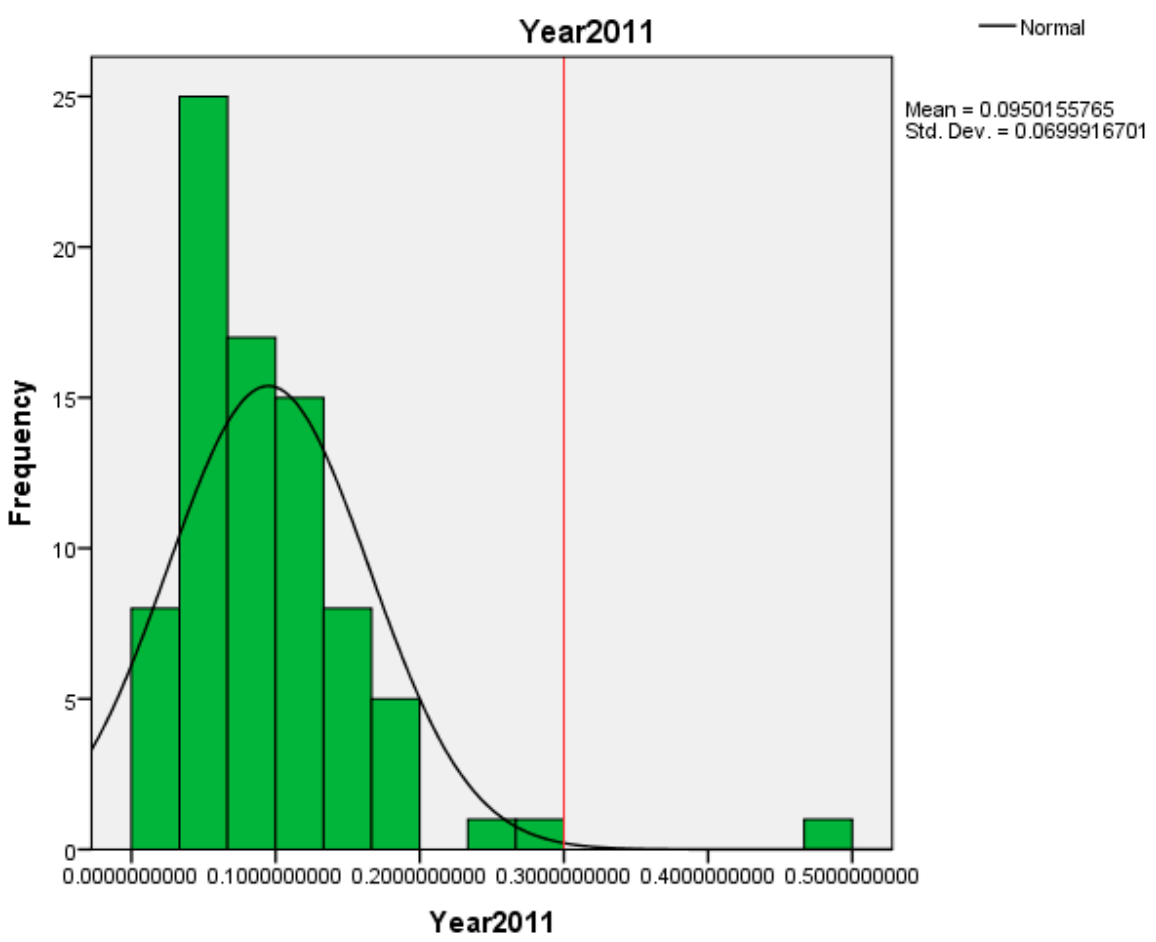

Figure 2. Histogram showing the Std. Devs. in IBM-SPSS for the variable analyzed for the year 2011. Source: Author's computation in IBM SPSS.

Table 2. Ranking a and $\mathrm{b}$ parameters for the variables in the Z-score function.

\begin{tabular}{ccccc}
\hline Variables & Symbol $^{\mathbf{1}}$ & Parameter a & Parameter b & $\%$ \\
\hline ROA & P1 & 2.032051978 & -0.001581337 & $24.91 \%$ \\
Operating profit margin & P3 & 1.936599118 & -0.017859762 & $23.74 \%$ \\
ESG & ESG & 1.171556088 & -0.107123814 & $14.36 \%$ \\
Long-term debt ratio & D3 & 0.995227225 & -0.000008928 & $12.20 \%$ \\
Solvency ${ }^{2}$ & S2 & 0.784753639 & -0.056025349 & $9.62 \%$ \\
Total assets turnover & A1 & 0.581538108 & -0.000596670 & $7.13 \%$ \\
ROE & P2 & 0.182699172 & -0.000416209 & $2.24 \%$ \\
Equity multiplier & D1 & 0.075495118 & -0.076391673 & $0.93 \%$ \\
Debt-to-equity ratio & D2 & 0.075495118 & -0.000896555 & $0.93 \%$ \\
\hline
\end{tabular}


Table 2. Cont.

\begin{tabular}{ccccc}
\hline Variables & Symbol $^{\mathbf{1}}$ & Parameter a & Parameter b & \% \\
\hline Cash ratio & L3 & 0.066687383 & -0.000004827 & $0.82 \%$ \\
Net profit margin & P4 & 0.047918136 & -0.000037562 & $0.59 \%$ \\
Inventory turnover & A3 & 0.045891095 & -0.002291720 & $0.56 \%$ \\
Quick ratio & L2 & 0.037825541 & -0.000084211 & $0.46 \%$ \\
Current ratio & L1 & 0.037526071 & -0.000083544 & $0.46 \%$ \\
Solvency 1 & S1 & 0.032257654 & -0.002450579 & $0.40 \%$ \\
Fixed assets turnover & A2 & 0.019838478 & -0.000112619 & $0.24 \%$ \\
Intangible assets turnover & A4 & 0.019252365 & -0.000206717 & $0.24 \%$ \\
RORC & P5 & 0.008334616 & -0.000004827 & $0.10 \%$ \\
P/E ratio & M1 & 0.003228197 & -0.000550215 & $0.04 \%$ \\
P/B ratio & M2 & 0.002196156 & -0.000066079 & $0.03 \%$ \\
EV/Net income & M4 & 0.000645724 & -0.000649634 & $0.01 \%$ \\
Tobin's Q & M3 & 0.000075432 & -0.000001434 & $0.00 \%$ \\
TOTAL & & 8.157092411 & & $100 \%$ \\
\hline
\end{tabular}

1 A-assets; D-debt; ESG—environmental, social, and corporate governance; L-liquidity; M-market; $\mathrm{P}$-profitability; S-solvency. Source: Author's computation in Excel.

The descriptions and calculation formulas for the variables shown in Table 2 can be found in Appendix B. The variables highlighted in grey color in Table 2 were those included in the Z-score function. Their selection was based on the parameter of importance $a$, starting with the highest values. Furthermore, summing the weights of the chosen variables (seven variables) resulted in more than $90 \%$ of the weights of the total (22) variables included in the analysis.

The Z-score function that resulted after the application of the methodology consisting of seven variables, those with the highest parameters:

$$
\begin{aligned}
& \mathrm{Z}-\text { score function }=\mathrm{a}_{1} \times \mathrm{P}_{1}+\mathrm{a}_{2} \times \mathrm{P}_{3}+\mathrm{a}_{3} \times \mathrm{ESG} \pm \mathrm{a}_{4} \times \mathrm{D}_{3}+\mathrm{a}_{5} \times \mathrm{S}_{2}+\mathrm{a}_{6} \times \mathrm{A}_{1}+\mathrm{a}_{7} \times \mathrm{P}_{2}+\sum \mathrm{b} \\
& \mathrm{Z} \text { - score function }=2.032 \times \mathrm{P}_{1}+1.937 \times \mathrm{P}_{3}+1.172 \times \mathrm{ESG} \pm 0.995 \times \mathrm{D}_{3}+0.785 \times \mathrm{S}_{2}+0.582 \times \mathrm{A}_{1}+0.183 \times \mathrm{P}_{2}+\sum \mathrm{b} .
\end{aligned}
$$

The variable D3, the long-term debt-to-equity ratio or the financial leverage, indicates how the company finances its operations - either with debt and/or equity-and is used in the Z-score function with + or -, depending on how the company stands compared with the sector average. This variable does not have an optimal value, each company chooses how much leverage they want to use (the higher the leverage, the higher the risk), where debt is a cheaper financing source than equity. In the end, the sector is characterized by an average level of financial leverage. If a company is below this average (calculated on an annual basis), D3 is used with + to meet the average, and vice-versa.

A Pearson correlation analysis was conducted on the seven variables used in the Zscore function. The results of the Pearson correlation analysis were interpreted, according to Evans [66], as follows:

- $\quad$ Statistical significance was at the 0.01 level;

- Intensity between the variables: 0.00-0.19, very weak; 0.20-0.39], weak; 0.40-0.59, moderate; $0.60-0.79$, strong; $0.80-1.0$, very strong;

- Sense of the correlation: positive "+" or negative "-".

Based on the results of the Pearson correlation analysis (see Appendix C), we made the following observations:

- between the variables Solvency 2 and Long-term debt ratio, there was a negative $(-1.000)$, very strong $(1.000>0.80)$, and statistically significant (Sig. $(2$-tailed $)<0.01)$ relationship; a perfect negative correlation means the relationship that exists between two variables is exactly opposite all of the time. In this case, the perfect correlation between the two variables could be explained by the fact that the variables have a common denominator (Shareholders Equity + Long-term debt). For Solvency 2, the 
numerator is Shareholder Equity while, for the Long-term debt ratio, the numerator is Long-term debt. These two variables show the share of long-term financing sources of shareholders and creditors. If the share of shareholder financing sources decreases by $\mathrm{x} \%$, then the share of creditor financing sources increases by the same $\mathrm{x} \%$.

- between the variable ROE and ROA, there was a positive $(+0.648)$, strong $(0.648>0.60)$, and statistically significant (Sig. (2-tailed) < 0.01) relationship;

- $\quad$ between ROE and the variables Operating Profit Margin (+0.485), Solvency $2(+0.410)$, and Long-term debt $(+0.403)$, there were moderate $(0.485,0.410$, and $0.403>0.40)$, and statistically significant (Sig. (2-tailed) < 0.01) relationships;

- between the other variables, there were negative and positive, low and very low, and statistically significant (Sig. (2-tailed) < 0.01) relationships.

From a mathematical point of view, the correlations (existence of some connections) between the values of the variables were expected but, looking at the financial standing, each variable represents a distinct indicator of financial performance. In the Z-score function, the variables included according to the parameters of importance were the ROA, which measures the company's ability to make a satisfactory net profit by using its assets; ROE, which measures the return on equity (i.e., the financial investment) that shareholders have created by buying the company's shares; ESG, which measures sustainability based on the environmental, social, and governance pillars; Operating profit margin, which measures how efficiently a company can generate profit from its operating activity; Long-term debt (or financial leverage), which measures how much of the total funds to finance the company's wealth are provided by long-term debt; Solvency 2 , which measures the company's ability to meet its obligations to its creditors, on account of shareholder equity; and Total assets turnover, which measures the turnover of all the company's assets $[62,67,68]$.

Applying the Z-score function to the data sample, we obtained the results shown in Appendix D, Table A4.

Normalizing the Z-score function according to the methodology detailed above, we obtained scores in a range between 10 and 100. A company with a score of 10 is ranked as the worst, in terms of performance, while 100 is the best score possible for a company to obtain. The normalization process of the Z-score function was applied to the whole sample. In Table 3, the results for 25 companies are given; the scores for the entire sample of 100 companies can be found in Appendix D, Table A5.

The colors in Table 3 represent the intervals in which we can find the scores, as follows:

- Green-scores between 90 and 100;

- $\quad$ Orange-scores between 70 and 90;

- Yellow-scores between 50 and 70; and

- $\quad$ Red-scores lower than 50.

In addition, a ranking of the sampled companies was created, based on the performance growth index. It can be seen that this ranking differed significantly from the ranking according to the market capitalization, as presented in Tables 4 and 5.

The top 10 companies ranked by market capitalization in the sample analyzed $(n=100)$ occupied lower positions (between 53 and 96), from the perspective of the average performance growth index. Additionally, it captured the company's performance in terms of its multi-dimensional aspect and was not only limited to the aspect of market value. 
Table 3. Normalized Z-score, first 25 companies in the pharmaceutical sector, 2020-2011 (for the entire sample of 100 companies, see Appendix D).

\begin{tabular}{|c|c|c|c|c|c|c|c|c|c|c|}
\hline Company Name & 2020 & 2019 & 2018 & 2017 & 2016 & 2015 & 2014 & 2013 & 2012 & 2011 \\
\hline Johnson \& Johnson & 84.83 & 84.43 & 87.44 & 91.79 & 91.23 & 84.59 & 93.36 & 84.82 & 89.85 & 79.38 \\
\hline Pfizer Inc. & 72.11 & 66.67 & 63.94 & 80.94 & 75.80 & 67.86 & 77.23 & 74.65 & 76.58 & 70.10 \\
\hline Eli Lilly and Co. & 69.41 & 61.10 & 78.72 & 84.97 & 75.24 & 69.17 & 76.75 & 84.09 & 85.33 & 82.02 \\
\hline Merck \& Co. Inc. & 85.36 & 87.09 & 90.98 & 88.68 & 84.92 & 75.07 & 83.24 & 73.71 & 85.04 & 79.18 \\
\hline Abbvie Inc. & 59.08 & 56.25 & 58.53 & 68.86 & 68.40 & 53.89 & 52.13 & 57.54 & 49.50 & 66.58 \\
\hline Bristol-Myers Squibb Co. & 63.81 & 71.83 & 92.23 & 92.18 & 85.11 & 66.21 & 78.06 & 72.02 & 81.11 & 85.47 \\
\hline $\mathrm{Am}$ & 69.57 & 75.02 & 76.12 & 84.88 & 84.73 & 76.57 & 77.77 & 68.04 & 71.31 & 65.68 \\
\hline Novartis AG & 79.39 & 75.25 & 76.04 & 79.73 & 75.95 & 71.41 & 83.02 & 77.98 & 82.89 & 74.56 \\
\hline Roche Holding AG & 100 & 95.56 & 98.03 & 99.12 & 100 & 94.43 & 98.99 & 100 & 100 & 81.07 \\
\hline AstraZene & 77.19 & 69.64 & 66.01 & 80.52 & 79.59 & 78.90 & 79.58 & 74.54 & 93.13 & 91.36 \\
\hline Novo $\mathrm{N}$ & 70.82 & 70.48 & 66.00 & 79.35 & 74.53 & 68.76 & 71.09 & 68.73 & 72.99 & 100 \\
\hline & 79.80 & 71.08 & 70.39 & 79.73 & 75.45 & 71.06 & 78.50 & 74.45 & 78.44 & 67.53 \\
\hline CSL & 94.98 & 93.12 & 96.08 & 92.39 & 90.10 & 100 & 100 & 94.09 & 96.55 & 86.79 \\
\hline GlaxoSmit & 79.90 & 72.88 & 64.11 & 63.48 & 62.43 & 65.99 & 72.78 & 81.63 & 79.02 & 80.95 \\
\hline Zoet & 75.18 & 69.63 & 65.29 & 67.09 & 64.22 & 44.80 & 66.65 & 45.74 & 58.37 & 51.16 \\
\hline Otsuka Hol & 73.16 & 67.76 & 57.49 & 65.58 & 61.43 & 55.86 & 59.10 & 65.11 & 66.65 & 48.75 \\
\hline Chugai Pharma & 66.29 & 56.25 & 69.95 & 75.18 & 69.10 & 68.07 & 76.07 & 73.33 & 76.22 & 45.13 \\
\hline Bayer AG & 71.61 & 72.75 & 69.67 & 81.50 & 73.92 & 70.52 & 78.46 & 77.26 & 81.25 & 71.34 \\
\hline iichi $S$ & 74.08 & 64.74 & 62.52 & 69.70 & 71.65 & 59.34 & 69.90 & 67.67 & 77.71 & 66.87 \\
\hline Takeda Pharmaceutical Co. Ltd. & 64.80 & 60.54 & 67.28 & 72.29 & 67.39 & 55.18 & 64.21 & 61.58 & 69.13 & 70.75 \\
\hline Samsung Biologics Co. Ltd. & 64.25 & 52.40 & 44.22 & 55.16 & 31.16 & 25.16 & 39.11 & 32.33 & 12.19 & 11.23 \\
\hline Biogen Inc. & 97.75 & 100 & 100 & 100 & 93.38 & 93.27 & 96.96 & 85.76 & 92.11 & 81.53 \\
\hline Alexion Phar & 78.51 & 75.58 & 57.47 & 60.08 & 55.95 & 46.34 & 82.36 & 70.98 & 75.63 & 43.79 \\
\hline Astellas & 82.56 & 84.03 & 85.38 & 91.97 & 87.67 & 77.76 & 80.60 & 73.05 & 45.77 & 41.66 \\
\hline Changchun High \& New Technolog & 78.28 & 72.29 & 62.96 & 66.82 & 59.78 & 58.33 & 67.71 & 67.12 & 71.26 & 51.55 \\
\hline
\end{tabular}

Source: Author's computation in Excel. These colors are used to highlight the difference in scores.

Table 4. Top 10 companies in the pharmaceutical sector, ranked by stock market capitalization vs. ranked by average growth index of the performance score.

\begin{tabular}{cccccc}
\hline $\begin{array}{c}\text { Company Name } \\
\text { (A) }\end{array}$ & $\begin{array}{c}\text { Stock Market } \\
\text { Capitalization } \\
\mathbf{( B )}\end{array}$ & $\begin{array}{c}\text { Ranking by Stock } \\
\text { Market Capitalization } \\
\text { (C) }\end{array}$ & $\begin{array}{c}\text { Average } \\
\text { Growth Index } \\
\text { (D) }\end{array}$ & $\begin{array}{c}\text { Ranking by an } \\
\text { Average Growth Index } \\
\text { (E) }\end{array}$ & $\begin{array}{c}\text { Difference } \\
\text { in Rankings } \\
\text { (C-E) }\end{array}$ \\
\hline Johnson \& Johnson & $\$ 421,022,434,674.40$ & 1 & 1.008298926 & 60 & -59 \\
Roche Holding & $\$ 292,100,941,230.87$ & 2 & 1.018090905 & 53 & -51 \\
Novartis & $\$ 213,647,903,609.71$ & 3 & 1.007153289 & 62 & -59 \\
Pfizer & $\$ 207,340,357,887.18$ & 4 & 1.003581429 & 59 & -54 \\
Merck \& Co. & $\$ 193,391,338,870.80$ & 5 & 1.010652165 & 50 & -74 \\
Abbvie & $\$ 186,895,052,749.50$ & 6 & 0.989146158 & 93 & -86 \\
Eli Lilly and Co. & $\$ 175,495,565,097.00$ & 7 & 1.003351613 & 66 & -58 \\
Amgen & $\$ 143,731,814,308.74$ & 8 & 0.964430486 & 96 & -87 \\
Bristol-Myers & $\$ 142,546,941,596.16$ & 9 & 0.979735963 & & 91 \\
Squibb Co. & $\$ 131,510,755,321.28$ & 10 & & & -81 \\
AstraZeneca & & &
\end{tabular}

Source: Author's computation in Excel.

The bottom 10 companies ranked by market capitalization in the sample analyzed $(n=100)$ occupied higher positions (between 6 and 82) from the perspective of the average performance growth index. These differences in rankings provide proof that market capitalization is not entirely representative in capturing company performance. 
Table 5. Bottom 10 companies in the pharmaceutical sector from our data sample, ranked by stock market capitalization vs. ranked by average growth index of the performance score.

\begin{tabular}{|c|c|c|c|c|c|}
\hline $\begin{array}{c}\text { Company Name } \\
\text { (A) }\end{array}$ & $\begin{array}{l}\text { Stock Market } \\
\text { Capitalization } \\
\text { (B) }\end{array}$ & $\begin{array}{c}\text { Ranking by Stock } \\
\text { Market Capitalization } \\
\text { (C) }\end{array}$ & $\begin{array}{l}\text { Average } \\
\text { Growth Index } \\
\text { (D) }\end{array}$ & $\begin{array}{c}\text { Ranking by an } \\
\text { Average Growth Index } \\
\text { (E) }\end{array}$ & $\begin{array}{c}\text { Difference } \\
\text { in Rankings } \\
\text { (C-E) }\end{array}$ \\
\hline $\begin{array}{l}\text { OPKO Health Inc. } \\
\text { Jilin Aodong }\end{array}$ & $\$ 2,817,498,852.80$ & 91 & 1.182630652 & 8 & 83 \\
\hline $\begin{array}{l}\text { Pharmaceutical } \\
\text { Group }\end{array}$ & $\$ 2,774,691,098.60$ & 92 & 1.101729822 & 19 & 73 \\
\hline Almirall & $\$ 2,670,351,354.50$ & 93 & 1.109985819 & 16 & 77 \\
\hline $\begin{array}{l}\text { Zhejiang Hisun } \\
\text { Pharmaceutical }\end{array}$ & $\$ 2,588,458,339.99$ & 94 & 0.999514548 & 71 & 23 \\
\hline $\begin{array}{c}\text { Alembic } \\
\text { Pharmaceuticals }\end{array}$ & $\$ 2,558,099,445.17$ & 95 & 0.999246331 & 72 & 23 \\
\hline $\begin{array}{l}\text { Jiangsu Nhwa } \\
\text { Pharmaceutical }\end{array}$ & $\$ 2,299,278,167.47$ & 96 & 1.002169573 & 68 & 28 \\
\hline $\begin{array}{l}\text { Zhejiang Starry } \\
\text { Pharmaceutical }\end{array}$ & $\$ 2,289,186,178.09$ & 97 & 1.195674036 & 6 & 91 \\
\hline Virbac & $\$ 2,263,280,372.72$ & 98 & 1.030694763 & 39 & 59 \\
\hline $\begin{array}{l}\text { Luye Pharma } \\
\text { Group }\end{array}$ & $\$ 2,086,697,816.22$ & 99 & 1.104396302 & 18 & 81 \\
\hline $\begin{array}{l}\text { Sawai Group } \\
\text { Holdings }\end{array}$ & $\$ 2,072,107,374.97$ & 100 & 0.988802842 & 82 & 18 \\
\hline
\end{tabular}

Source: Author's computation in Excel.

\section{Discussion and Conclusions}

The average growth index of the performance score, calculated in the period 2011-2020 for the 100 companies analyzed, showed an increase in performance for 70 companies out of the 100 analyzed. This result shows that there is a direct and positive link between the M\&A process and the evolution of the performance of companies in the pharmaceutical sector. Furthermore, it can be observed that, in the analyzed period, both at the level of the entire pharmaceutical sector and at the level of the analyzed sample, acquisition transactions predominated, that is, acquisitions of assets, acquisitions of remaining interest, acquisitions of majority assets, acquisitions of partial interest, and acquisitions of certain assets. The highest share of these (over 30\%) was represented by the acquisition of assets, as can be seen in Table 6 .

Table 6. M\&A transactions, total companies vs. 100 sample companies from the pharmaceutical sector, 2010-2020.

\begin{tabular}{|c|c|c|c|c|c|c|c|c|}
\hline Transactions & Merger & $\begin{array}{l}\text { Acquisition } \\
\text { of Assets }\end{array}$ & $\begin{array}{l}\text { Acquisition of } \\
\text { Remaining } \\
\text { Interest }\end{array}$ & Buyback & $\begin{array}{c}\text { Acquisition } \\
\text { of Majority } \\
\text { Assets }\end{array}$ & $\begin{array}{c}\text { Acquisition } \\
\text { of Partial } \\
\text { Interest }\end{array}$ & $\begin{array}{c}\text { Exchange } \\
\text { Offer }\end{array}$ & $\begin{array}{l}\text { Acquisition } \\
\text { of Certain } \\
\text { Assets }\end{array}$ \\
\hline $\begin{array}{c}1663 \text { complete } \\
\text { transactions }\end{array}$ & $34 \%$ & $35 \%$ & $3 \%$ & $3 \%$ & $11 \%$ & $12 \%$ & $1 \%$ & $1 \%$ \\
\hline $\begin{array}{l}492 \text { complete } \\
\text { transactions }\end{array}$ & $39 \%$ & $31 \%$ & $3 \%$ & $4 \%$ & $9 \%$ & $14 \%$ & $0 \%$ & $0 \%$ \\
\hline
\end{tabular}

Source: Author's computation in Excel.

The analysis highlighted the fact that the ESG score, as an indicator for measuring sustainability, has a strong, positive, and direct impact on the evolution of company performance in the pharmaceutical sector, occupying the 3rd position, with a parameter $a$ of 1.171556088 and a weight of $14.36 \%$ out of the total.

Although investors traditionally value company performance against market value indicators (e.g., P/E, P/B, EV/Net Income, and Tobin's Q), the results of our analysis showed that market value is a component of the company's performance but, in the case of the pharmaceutical sector-especially on the sample of the 100 companies in our analysisit is not a determining one, the proof being the very low value of the parameters $a$ calculated 
in this study $(\mathrm{P} / \mathrm{E}-0.003228197,0.04 \%$ out of the total; $\mathrm{P} / \mathrm{B}-0.002196156,0.03 \%$ out of the total; EV / Net Income- $0.000645724,0.01 \%$ out of the total, and Tobin's Q-0.000075432, $0.001 \%$ out of the total). This idea is also supported by the fact that there are significant differences between market capitalization ranking and average performance growth index ranking.

In conclusion, our study showed that both M\&A transactions and sustainability (measured through the ESG score) had a direct and favorable impact on the performance of companies in the pharmaceutical sector analyzed globally, during 2011-2020.

The limitation of this exploratory study arises from the fact that we took into consideration only publicly listed companies that performed at least one M\&A transaction in the analyzed period. The results of this study have generated new directions for future research. Given the fact that there has been a predisposition towards acquisitions, especially asset acquisitions, a future research direction aims to analyze the impact of different types of transactions on company performance. In this sense, separate samples should be created and analyzed, based on the criterion of the type of transaction. Furthermore, we could perform a comparative analysis between the evolution of the performance of companies that did not perform any type of M\&A transaction and those that used such strategies at the level of the same sector of activity, in order to better capture the impact of M\&A on the evolution of performance.

Author Contributions: Conceptualization, D.M.M. and R.-A.S.; methodology, R.-A.S. and M.T,.; software, A.O.; validation, M.T., A.O. and V.B.; formal analysis, V.B. and R.-A.Ș.; investigation, D.M.M.; resources, A.O.; data curation, M.T,.; writing-original draft preparation, D.M.M., L.B. and R.-A.S.; writing—review and editing, D.M.M., L.B. and R.-A.Ș.; visualization, D.M.M. and R.-A.S,; supervision, V.B.; project administration, D.M.M.; funding acquisition, D.M.M. All authors have read and agreed to the published version of the manuscript.

Funding: This research was funded by Lucian Blaga University of Sibiu and Hasso Plattner Foundation, grant number LBUS-IRG-2020-06.

Institutional Review Board Statement: Not applicable.

Informed Consent Statement: Not applicable.

Data Availability Statement: Third-party data restrictions apply to the availability of these data. Data were obtained from Thomson Reuters Eikon and are available at https://emea1.apps.cp. thomsonreuters.com/web/Apps/Corp?s=JNJ\&st=RIC\&app=true (accessed on 17 April 2021) with the permission of Thomson Reuters Eikon.

Acknowledgments: Project financed by Lucian Blaga University of Sibiu and Hasso Plattner Foundation research grants LBUS-IRG-2020-06.

Conflicts of Interest: The authors declare no conflict of interest. The funders had no role in the design of the study; in the collection, analyses, or interpretation of data; in the writing of the manuscript, or in the decision to publish the results.

\section{Appendix A}

Table A1. Std. Dev. results for the variables analyzed (i.e., Operating Profit Margin).

\begin{tabular}{|c|c|c|c|c|c|c|c|c|c|c|}
\hline Company Name & $\begin{array}{c}\text { ZAYear } \\
2020\end{array}$ & $\begin{array}{c}\text { ZAYear } \\
2019\end{array}$ & $\begin{array}{c}\text { ZAYear } \\
2018\end{array}$ & $\begin{array}{c}\text { ZAYear } \\
2017\end{array}$ & $\begin{array}{c}\text { ZAYear } \\
2016\end{array}$ & $\begin{array}{c}\text { ZAYear } \\
2015\end{array}$ & $\begin{array}{c}\text { ZAYear } \\
2014\end{array}$ & $\begin{array}{c}\text { ZAYear } \\
2013\end{array}$ & $\begin{array}{c}\text { ZAYear } \\
2012\end{array}$ & $\begin{array}{c}\text { ZAYear } \\
2011\end{array}$ \\
\hline Johnson \& Johnson & 0.69160 & 0.80738 & 0.66201 & 0.76384 & 0.84178 & 0.62468 & 0.93299 & 0.92167 & 0.64278 & 0.15249 \\
\hline Pfizer Inc. & 0.83501 & 0.23889 & 0.12684 & 0.89416 & 0.68967 & 0.80024 & 0.97193 & 1.35992 & 1.29230 & 1.17508 \\
\hline Eli Lilly and Co. & 0.83008 & 0.51776 & 0.61237 & 0.21375 & -0.21864 & -0.09042 & -0.24834 & 0.49396 & 0.29423 & 0.69758 \\
\hline Merck \& Co Inc. & 0.99490 & 1.28227 & 1.23466 & 1.31196 & 2.00111 & 1.47861 & 0.25221 & 0.19765 & 1.53149 & 1.39623 \\
\hline Abbvie Inc. & 0.90526 & 1.86019 & 1.57803 & 1.49930 & 1.48045 & 1.38675 & -0.06568 & 1.27856 & 1.60545 & 0.70590 \\
\hline Bristol-Myers Squibb Co. & -0.54140 & 0.86493 & 1.29999 & 1.13158 & 0.60895 & -0.66215 & 0.09033 & 0.01569 & 0.72046 & 1.37586 \\
\hline Amgen Inc. & 1.63883 & 1.94276 & 2.18525 & 2.33042 & 1.93294 & 1.83118 & 1.28112 & 1.36198 & 1.50338 & 1.44194 \\
\hline Novartis AG & 0.50555 & 0.27826 & 0.13484 & 0.09545 & -0.18693 & 0.07727 & 0.29578 & 0.30180 & 0.14702 & 0.23576 \\
\hline Roche Holding AG & 1.29674 & 1.15570 & 1.14490 & 1.08968 & 1.12800 & 1.29029 & 1.57613 & 1.76288 & 1.81191 & 1.54125 \\
\hline
\end{tabular}


Table A1. Cont.

\begin{tabular}{|c|c|c|c|c|c|c|c|c|c|c|}
\hline Company Name & $\begin{array}{c}\text { ZAYear } \\
2020\end{array}$ & $\begin{array}{c}\text { ZAYear } \\
2019\end{array}$ & $\begin{array}{l}\text { ZAYear } \\
2018\end{array}$ & $\begin{array}{c}\text { ZAYear } \\
2017\end{array}$ & $\begin{array}{c}\text { ZAYear } \\
2016\end{array}$ & $\begin{array}{c}\text { ZAYear } \\
2015\end{array}$ & $\begin{array}{l}\text { ZAYear } \\
2014\end{array}$ & $\begin{array}{c}\text { ZAYear } \\
2013\end{array}$ & $\begin{array}{l}\text { ZAYear } \\
2012\end{array}$ & $\begin{array}{c}\text { ZAYear } \\
2011\end{array}$ \\
\hline AstraZeneca PLC & .23659 & -0.42758 & 0.79111 & 0.23230 & 0.01472 & 14873 & .12074 & 43321 & 1.02401 & 1.47200 \\
\hline Novo Nord & & & & & & & & & 26 & 681 \\
\hline Sanofi SA & 362 & 3374 & 8486 & 04612 & 198 & 4467 & 5689 & & 994 & 3455 \\
\hline CSL Ltd & 720 & 1.02942 & 1.08431 & 625 & 214 & 439 & 565 & 589 & 2934 & 4344 \\
\hline GlaxoSmithKline PLC & 002 & & & & 887 & 277 & 3041 & 94 & 5837 & 7790 \\
\hline Zoetis Inc. & 136 & & & 1.2 & 793 & 494 & 873 & 2551 & 0.13154 & 29618 \\
\hline Otsuka Holdings Co. Ltd & -0.52284 & -0.71706 & -1.26499 & -1.20455 & -1.19644 & -0.84525 & \#N/A & 45762 & -0.66259 & 77740 \\
\hline Chugai Pharmaceutical Co Ltd & 1.87358 & 0.94986 & 0.13051 & -0.13125 & -0.44927 & -0.14439 & -0.29861 & 02829 & -0.00790 & 24235 \\
\hline Bayer AG & -0.26767 & -0.38440 & -0.31620 & 0.02975 & -0.13468 & 4243 & 55787 & 744 & -0.50802 & 54359 \\
\hline Daiichi Sankyo Co. Ltd & -0.55656 & -1.02225 & -1.05773 & -0.97926 & -0.66268 & -0.98046 & -0.67618 & -0.86278 & 0.13314 & -0.67774 \\
\hline $\begin{array}{c}\text { Takeda Pharmaceutical Co. } \\
\text { Ltd }\end{array}$ & -1.10340 & -1.04536 & -0.74858 & -0.81984 & -1.11172 & -1.25964 & -1.02439 & -1.30429 & -0.19206 & 0.68223 \\
\hline Samsung Biologics Co. Ltd & 0.55068 & -0.65188 & -0.84231 & -0.52901 & $\# \mathrm{~N} / \mathrm{A}$ & \#N/A & $\# \mathrm{~N} / \mathrm{A}$ & $\# \mathrm{~N} / \mathrm{A}$ & $\# \mathrm{~N} / \mathrm{A}$ & $\# \mathrm{~N} / \mathrm{A}$ \\
\hline Biogen Inc. & & & & 2.3 & 048 & 398 & 5997 & & 973 & 9540 \\
\hline Alexion Pharmaceuticals Inc. & 2.66174 & 2.03 & & & 0.34077 & 0.42517 & 2.08288 & 1.75735 & 1.67054 & 1.22024 \\
\hline $\begin{array}{l}\text { Astellas Pharma Inc. } \\
\text { Changchun High \& New }\end{array}$ & 0.17677 & 0.16536 & 0.1 & 0.0 & -0.11059 & -0.19015 & -0.29608 & -0.21074 & -0.61234 & -0.66901 \\
\hline $\begin{array}{c}\text { Technology Industries Group } \\
\text { Inc. }\end{array}$ & 2.53954 & 1.59812 & 1.08441 & 0.71304 & 0.53779 & 0.57274 & 0.38409 & 0.79489 & 0.79089 & -0.32733 \\
\hline Canopy Growth Corp & $\# \mathrm{~N} / \mathrm{A}$ & $\# \mathrm{~N} / \mathrm{A}$ & $\# \mathrm{~N} / \mathrm{A}$ & $\# \mathrm{~N} / \mathrm{A}$ & $\# \mathrm{~N} / \mathrm{A}$ & \#N/A & $\# \mathrm{~N} / \mathrm{A}$ & $\# \mathrm{~N} / \mathrm{A}$ & $\# \mathrm{~N} / \mathrm{A}$ & $\# \mathrm{~N} / \mathrm{A}$ \\
\hline Ucb & 0.08367 & 0.21165 & 0.35812 & 0.46 & 3439 & 7004 & -0.79504 & -0.90592 & -0.69039 & 4269 \\
\hline Trulieve Ca & 2.23516 & 2.23551 & \#N/A & \#N & \#N/A & /A & $\# \mathrm{~N} / \mathrm{A}$ & $\# \mathrm{~N} / \mathrm{A}$ & \#N/A & $\# \mathrm{~N} / \mathrm{A}$ \\
\hline $\begin{array}{c}\text { Torrent Pharmaceuticals Ltd } \\
\text { Tilray Inc. }\end{array}$ & $\begin{array}{l}-0.05391 \\
\# \mathrm{~N} / \mathrm{A}\end{array}$ & $\begin{array}{l}-0.21890 \\
\# \mathrm{~N} / \mathrm{A}\end{array}$ & $\begin{array}{l}-0.36537 \\
\# \mathrm{~N} / \mathrm{A}\end{array}$ & $\begin{array}{l}-0.13258 \\
\# \mathrm{~N} / \mathrm{A}\end{array}$ & $\begin{array}{l}1.46830 \\
\# \mathrm{~N} / \mathrm{A}\end{array}$ & $\begin{array}{l}-0.10589 \\
\text { \#N/A }\end{array}$ & $\begin{array}{l}0.31414 \\
\# \mathrm{~N} / \mathrm{A}\end{array}$ & $\begin{array}{l}0.04606 \\
\# \mathrm{~N} / \mathrm{A}\end{array}$ & $\begin{array}{l}-0.31725 \\
\# N / A\end{array}$ & $\begin{array}{l}-0.43153 \\
\# \mathrm{~N} / \mathrm{A}\end{array}$ \\
\hline $\begin{array}{l}\text { Teva Pharmaceutical } \\
\text { Industries Ltd }\end{array}$ & -0.06599 & -0.36121 & -0.28401 & -0.17432 & 0.00966 & 0.45890 & 0.24591 & 0.04266 & -0.20213 & 0.28156 \\
\hline $\begin{array}{c}\text { Sun Pharmaceutical Industries } \\
\text { Ltd }\end{array}$ & -0.43785 & -0.30693 & -0.34019 & 0.67905 & 0.53572 & .56750 & 2.2 & 742 & 698 & 1.17408 \\
\hline $\begin{array}{l}\text { Swedish Orphan Biovitrum } \\
\text { AB (publ) }\end{array}$ & 0.96419 & 1.21735 & 1.25632 & 0.50107 & 0.09350 & -1.29355 & -1.75033 & $\# \mathrm{~N} / \mathrm{A}$ & $\# \mathrm{~N} / \mathrm{A}$ & $\# \mathrm{~N} / \mathrm{A}$ \\
\hline Dr.Reddy's Laboratories Ltd & -0.26104 & -0.63131 & -0.97177 & -0.84393 & -0.07888 & -0.06394 & -0.01206 & -0.05921 & 0.01494 & -0.37448 \\
\hline $\begin{array}{c}\text { Recordati Industria Chimica e } \\
\text { Farmaceutica SpA }\end{array}$ & 1.31317 & 1.01573 & 1.14472 & 1.08526 & 0.77415 & 0.71317 & 0.41969 & 0.32205 & 0.29195 & 0.23653 \\
\hline Perrigo Company PLC & -1.04508 & -1.03038 & -0.86054 & -0.52097 & -0.72266 & $\# \mathrm{~N} / \mathrm{A}$ & -0.41341 & 0.06186 & -0.12367 & -0.12958 \\
\hline Pacira Biosc & -.56183 & -1.06968 & -1.30087 & \#N/A & & -1.36672 & $\# \mathrm{~N} / \mathrm{A}$ & $\# \mathrm{~N} / \mathrm{A}$ & $\# \mathrm{~N} / \mathrm{A}$ & $\# \mathrm{~N} / \mathrm{A}$ \\
\hline OPKO Health Inc. & -1.56794 & \#N/A & $\# \mathrm{~N} / \mathrm{A}$ & $\# \mathrm{~N} / \mathrm{A}$ & \#N/A & $\# \mathrm{~N} / \mathrm{A}$ & \#N/A & $\# \mathrm{~N} / \mathrm{A}$ & \#N/A & $\# \mathrm{~N} / \mathrm{A}$ \\
\hline Mckesson Corp & -1.84394 & -1.70533 & -1.62500 & -1.66811 & -1.65811 & -1.54025 & -1.70205 & -1.63301 & -1.83702 & -1.73264 \\
\hline $\mathrm{Lu}$ & -1.05532 & -0.77146 & -0.60699 & 0.05778 & 0.17694 & 0.62369 & 0.55059 & 0.18196 & -0.17239 & -0.16591 \\
\hline $\mathrm{H}$ Lundb & -0.31297 & 0.11691 & 0.87304 & 0.5 & -0.53534 & \#N/A & -1.66324 & -0.65351 & 81284 & 0.21068 \\
\hline Kalbe Farr & -0.34621 & -0.42602 & -0.38513 & -0.36586 & -0.40252 & -0.34044 & -0.31918 & -0.27800 & 33293 & \#N/A \\
\hline Jazz Pharma & 0.21034 & 0.39843 & & 1.17187 & 795 & 2.08805 & 0.30330 & 2505 & 922 & 3.23107 \\
\hline Ips & 36 & 325 & 0.3 & 0.46841 & 252 & 369 & 07 & 521 & 8292 & -0.30872 \\
\hline IPCA Labc & 311 & -0.56077 & -1.00928 & -1.09072 & -1.31799 & 9879 & 0.2 & 0.0 & -0.06524 & -0.22219 \\
\hline Horizon The & & -0.84513 & -1.27217 & $\# \mathrm{~N} / \mathrm{A}$ & $\# \mathrm{~N} / \mathrm{A}$ & 5062 & $\mathrm{~A}$ & $\# \mathrm{~N} / \mathrm{A}$ & \#N/A & $\# \mathrm{~N} / \mathrm{A}$ \\
\hline Hyp & & 358 & & 366 & 412 & 164 & 26 & 0.56626 & 65 & 5187 \\
\hline Hikma Pharn & 234 & 795 & 0.1 & -0.00068 & 834 & 478 & 3730 & 0.99065 & 2276 & -0.42511 \\
\hline Green Thu & 060 & & & $\# \mathrm{~N} / \mathrm{A}$ & A & /A & $\mathrm{A}$ & $\mathrm{A}$ & A & \#N/A \\
\hline Elanco An & 0.5 & 0. & 0.8 & 0.7 & 0.9 & 571 & 91 & 7820 & 6505 & 8538 \\
\hline Dechra Phar & 3254 & -0.88594 & -0.78186 & -0.78278 & -0.66095 & -0.54037 & -0.61032 & -0.73006 & -0.77136 & -1.33755 \\
\hline Holding SE & -0.01038 & -0.16045 & 0.0 & -0.04683 & 2883 & 7259 & 7727 & \#N/A & $\# I$ & $\# \mathrm{~N} / \mathrm{A}$ \\
\hline Curaleaf Hol & $\# \mathrm{~N} / \mathrm{A}$ & \#N/A & $\# \mathrm{~N} / \mathrm{A}$ & \#N/A & \#N/A & \#N/A & \#N & $\# \mathrm{~N} / \mathrm{A}$ & \#N/A & \#N/A \\
\hline Catalen & -0.66084 & -0.78247 & -0.72077 & -0.71853 & -0.73362 & -0.34325 & 9436 & -0.59896 & -0.73294 & -0.52107 \\
\hline Cron & & \#N & H入 & $\# \mathrm{I}$ & $4 \pi$ & $4 \mathrm{~N}$ & $\#$ & $\# \mathrm{~N}$ & A & $\# \mathrm{~N} / \mathrm{A}$ \\
\hline Cresco Labs Inc. & 2617 & \#N/A & $\# \mathrm{~N}$ & \#N/A & \#N & $\# \mathrm{~N}$ & \#N & \#N & A & \#N/A \\
\hline $\mathrm{Ci}$ & 512 & -0.72514 & -0 . & -0.78993 & 2371 & -0.39407 & -0.20004 & 0.3 & 0. & 7243 \\
\hline Bausch Health Companies Inc. & 3310 & 3060 & -1 & -1. & -.7 & 0.140 & 34 & 267 & 9597 & 113 \\
\hline Aurobindo $\mathrm{Pl}$ & -0.26496 & -0.3 & -0.02481 & 0.00626 & -0.05702 & -0.0 & 0.29422 & -0 & 997 & 710 \\
\hline $\begin{array}{c}\text { Aspen Pharmacare Holdings } \\
\text { Ltd }\end{array}$ & 0.34944 & 0.42020 & 0.48626 & 0.35369 & 0.30445 & 0.47576 & 0.51870 & 0.80734 & 0.80687 & 0.81212 \\
\hline Aphria Inc. & A & \#N/A & \# & - & & $\pi$ & $m_{1}$ & $4 \mathrm{M}$ & 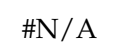 & /A \\
\hline & 9484 & 9347 & -1.09928 & $/ \mathrm{A}$ & & 717 & & & & \\
\hline ALK-A & -1.43471 & -1.75484 & $\# \mathrm{~N} / \mathrm{A}$ & -1.60878 & -0.42218 & -0.67943 & -0.64653 & 5693 & 2289 & -0.64471 \\
\hline Alembic Pharmaceuticals Ltd & 0.44849 & -0.12869 & -0.32359 & -0.25657 & 395 & -0.16416 & 24293 & 79 & 5885 & -0.83130 \\
\hline Abbott Laboratories & -0.40027 & -0.50991 & -0.68327 & -1.20760 & 3497 & -0.40334 & 57070 & & 831 & 18346 \\
\hline & -0.58975 & 0.85658 & & 0.64754 & & 1.1 & 1.3 & & 2.0 & 765 \\
\hline $\begin{array}{c}\text { Tasly Pharmaceutical Group } \\
\text { Co. Ltd }\end{array}$ & -0.93932 & -0.60882 & -0.61395 & -0.71385 & -0.49178 & -0.27005 & -0.54964 & -0.62199 & -0.84872 & -0.63504 \\
\hline $\begin{array}{c}\text { Zhejiang Hisun } \\
\text { Pharmaceutical Co. Ltd }\end{array}$ & -0.99035 & $\# \mathrm{~N} / \mathrm{A}$ & -1.48462 & -1.35570 & -1.62881 & -1.54567 & -1.13645 & -1.05234 & -1.49470 & -0.75933 \\
\hline $\begin{array}{l}\text { Shanghai Fosun } \\
\text { rmaceutical Group Co. }\end{array}$ & -1.10190 & -1.04936 & -0.94929 & $-0 . / 2585$ & -0.83872 & -0.73614 & -1.00319 & -0.82657 & -1.24751 & -1.42744 \\
\hline Beijing Tongrentang Co Ltd & -0.50213 & -0.55890 & -0.58943 & -0.19928 & -0.17154 & 0.05522 & 0.16715 & 0.25753 & 0.29689 & 0.22099 \\
\hline
\end{tabular}


Table A1. Cont.

\begin{tabular}{|c|c|c|c|c|c|c|c|c|c|c|}
\hline y Name & $\begin{array}{c}\text { ZAYear } \\
2020\end{array}$ & $\begin{array}{c}\text { ZAYear } \\
2019\end{array}$ & $\begin{array}{c}\text { ZAYear } \\
2018\end{array}$ & $\begin{array}{c}\text { ZAYear } \\
2017\end{array}$ & $\begin{array}{c}\text { ZAYear } \\
2016\end{array}$ & $\begin{array}{c}\text { ZAYear } \\
2015\end{array}$ & $\begin{array}{c}\text { ZAYear } \\
2014\end{array}$ & $\begin{array}{c}\text { ZAYear } \\
2013\end{array}$ & $\begin{array}{c}\text { ZAYear } \\
2012\end{array}$ & $\begin{array}{l}\text { ZAYear } \\
2011\end{array}$ \\
\hline $\begin{array}{l}\text { Humanwell Healthc } \\
\text { Co. Ltd }\end{array}$ & -0.86039 & -0.93128 & 9 & 1 & 9 & 19 & 68 & 982 & 09 & 23292 \\
\hline Oneness Biote & $\# \mathrm{~N} / \mathrm{A}$ & $\# \mathrm{~N} / \mathrm{A}$ & $\# \mathrm{~N} / \mathrm{A}$ & $\# \mathrm{~N} / \mathrm{A}$ & $\# \mathrm{~N} / \mathrm{A}$ & $\# \mathrm{~N} / \mathrm{A}$ & $\# \mathrm{~N} / \mathrm{A}$ & $\# \mathrm{~N} / \mathrm{A}$ & $\# \mathrm{~N} / \mathrm{A}$ & $\# \mathrm{~N} / \mathrm{A}$ \\
\hline s Co. Ltd & -1.23098 & -0.75584 & -0.59494 & -0.78451 & -0.95158 & -0.71876 & -0.52824 & -0.62526 & -0.54974 & $\# \mathrm{~N} / \mathrm{A}$ \\
\hline $\begin{array}{l}\text { JCR Pharma } \\
\text { Santen Pharm }\end{array}$ & $\begin{array}{l}-0.66193 \\
-0.31859\end{array}$ & $\begin{array}{l}0.10923 \\
-0.23271\end{array}$ & $\begin{array}{l}-0.13961 \\
-0.23860\end{array}$ & $\begin{array}{l}-0.63397 \\
-0.33446\end{array}$ & $\begin{array}{l}-0.74009 \\
1.79884\end{array}$ & $\begin{array}{l}-0.63378 \\
0.25660\end{array}$ & $\begin{array}{l}-0.93993 \\
0.08713\end{array}$ & $\begin{array}{l}-1.03286 \\
0.17828\end{array}$ & $\begin{array}{l}-1.14689 \\
0.41795\end{array}$ & $\begin{array}{l}-0.94778 \\
0.87211\end{array}$ \\
\hline $\begin{array}{c}\text { Hisamitsu Pharmac } \\
\text { Inc }\end{array}$ & -1 & -0.37517 & -0.38957 & -0.16573 & -0.23763 & -0.16814 & -0.62410 & -0.59603 & -0.17367 & -0.02912 \\
\hline $\begin{array}{l}\text { Ono Pharmaceutical Co. Ltd } \\
\text { Eisai Co Ltd } \\
\text { Shionogi \& Co. Ltd }\end{array}$ & $\begin{array}{l}0.68 \\
-0.0 \\
1.90\end{array}$ & $\begin{array}{l}0.15356 \\
-0.52095 \\
2.20194\end{array}$ & $\begin{array}{l}0.19119 \\
-0.63944 \\
1.18564\end{array}$ & $\begin{array}{l}1.02605 \\
-0.79798 \\
1.10276\end{array}$ & $\begin{array}{l}-0.15513 \\
-0.93974 \\
0.77587\end{array}$ & $\begin{array}{l}-0.72870 \\
-1.23935 \\
-0.05587\end{array}$ & $\begin{array}{l}-0.10475 \\
-0.84185 \\
0.17725\end{array}$ & $\begin{array}{l}0.20076 \\
-0.63574 \\
0.18529\end{array}$ & & $\begin{array}{l}0.69876 \\
-0.44487 \\
-0.25315\end{array}$ \\
\hline $\begin{array}{c}\text { Sumitomo Dainippon Pharma } \\
\text { Co Ltd }\end{array}$ & -0.5 & -0.74073 & -0.11012 & -0.52442 & -1.02183 & -1.14472 & -0.84003 & -1.12545 & -1.42672 & -1.10744 \\
\hline Kyowa K & -0.24575 & -0.23365 & -0.01018 & -0.20807 & -0.50209 & -0.62831 & -0.84214 & -0.35459 & -0.36915 & -0.57491 \\
\hline Phar & -1.48 & -1.40263 & -1.20476 & -1.27447 & -1.29677 & -1.16681 & -1.29241 & -1.13525 & $\# \mathrm{~N} / \mathrm{A}$ & $\# \mathrm{~N} / \mathrm{A}$ \\
\hline Porton Pha & -0.13800 & -0.70771 & -0.85002 & -0.39019 & -0.29254 & -0.41696 & -0.38938 & -0.05506 & -0.35172 & -0.48324 \\
\hline $\begin{array}{r}\text { Anhui Ar } \\
\text { Gro }\end{array}$ & 0.549 & 0.17898 & 0.28261 & 0.83603 & 0.41619 & 0.37998 & 0.24548 & 0.33577 & 0.12223 & -0.24213 \\
\hline $\begin{array}{r}\text { Innov } \\
\text { Sino Bio }\end{array}$ & & & & & & & & & & \\
\hline $\begin{array}{l}\text { CSPC Pharmaceut } \\
\text { Ltd }\end{array}$ & & & & & & & & & & -0.53137 \\
\hline $\begin{array}{r}\text { Guang } \\
\text { Pl }\end{array}$ & & & & & & & & & & 3673 \\
\hline $\begin{array}{r}\text { China Tradi } \\
\text { Me }\end{array}$ & -0.23935 & -0.29704 & -0.11512 & 0.10227 & -0.20291 & & & & & 9372 \\
\hline $\begin{array}{l}\text { China Gran } \\
\text { and Healthe }\end{array}$ & . & 0 & 0.0 & 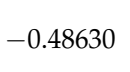 & 0.68986 & -0.72179 & 5 & -0.5 & 1.6 & 1.100 \\
\hline $\begin{array}{l}\text { Sihuan Phar } \\
\text { Holding }\end{array}$ & & 2 & & & & 4. & 4.3 & 3.78 & 1.49585 & 2.56686 \\
\hline Gre & -1.64 & -1.56165 & -1.42635 & -1.19101 & -1.25261 & -0.92161 & -0.9 & -0.96438 & -1.07583 & -0.80795 \\
\hline $\begin{array}{l}\text { Shenz } \\
\text { Pha }\end{array}$ & -0.02 & -0.346 & 0.06837 & -1.31707 & -0.58152 & 0.221 & -0.83502 & -0.87624 & 0.87809 & 0.38217 \\
\hline $\begin{array}{l}\text { Shen } \\
\text { Pharn }\end{array}$ & -0.4 & 0.0 & 1. & 1.83 & 1.85 & 2.0 & 2.0 & 2.1 & 92 & 0.99976 \\
\hline $\begin{array}{l}\text { Jiangsu Nhwa Pharmaceutical } \\
\text { Co Ltd }\end{array}$ & 0. & -0.2 & -0.4 & -0.6 & 48 & -0.71606 & -0.83792 & -0.89102 & -1.11237 & 698 \\
\hline $\begin{array}{l}\text { Yifan Pharmaceutical Co Ltd } \\
\text { China Resources Sanjiu }\end{array}$ & $0.14 \mathrm{C}$ & 0.24922 & 008207 & 1.57697 & 0.52807 & -0.30349 & -0.14592 & -0.56852 & A & 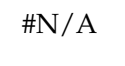 \\
\hline $\begin{array}{c}\text { Medical \& Pharmaceutical Co } \\
\text { Ltd }\end{array}$ & -0.4 & -0.66926 & -0.65113 & -0.58311 & -0.57383 & -0.28322 & -0.29901 & -0.04696 & -0.12885 & -0.27284 \\
\hline Apelo & -0.80890 & -0.96958 & -1.09256 & -1.14089 & -1.32551 & -1.20452 & -1.14533 & -1.26774 & -1.33801 & -1.39827 \\
\hline Jilin Aodor & & -1.00938 & -0.74395 & -0.55052 & -0.72673 & -0.54687 & -0.45703 & -0.83786 & -1.00115 & -1.38212 \\
\hline Yunnan Baiyao Group Co Ltd & -0.72966 & -0.95208 & -0.33740 & -0.54877 & -0.55100 & -0.35874 & -0.47884 & -0.62590 & -0.67358 & -0.73903 \\
\hline
\end{tabular}

\#N/A—data not available. Source: Author's computation in IBM SPSS.

\section{Appendix B}

Table A2. Variables and ESG Score.

\begin{tabular}{|c|c|c|c|}
\hline No. & Variables & Formulas and Description & Category \\
\hline 1 & Current ratio & $\begin{array}{l}\text { Current assets } \\
\text { Current liabilities, measures a company's ability to pay off short-term debt } \\
\text { with current assets [62] }\end{array}$ & \multirow{5}{*}{ Liquidity and solvency } \\
\hline 2 & Quick ratio & $\begin{array}{l}\frac{\text { Current assets - Inventories }}{\text { Current liabilities }}, \text { measures a company's ability to pay off } \\
\text { short-term debt with quick assets [62] }\end{array}$ & \\
\hline 3 & Cash ratio & $\begin{array}{l}\frac{\text { Cash and cash equivalents }}{\text { Current liabilities }}, \text { measures a company's ability to pay off short-term } \\
\text { liabilities with cash and cash equivalents [67] }\end{array}$ & \\
\hline 4 & $\begin{array}{l}\text { General } \\
\text { solvency }\end{array}$ & $\begin{array}{l}\text { Total assets } \\
\text { Total liabilities, measures the company's ability to meet its obligations to its } \\
\text { creditors on account of total assets [68] }\end{array}$ & \\
\hline 5 & $\begin{array}{l}\text { Patrimonial } \\
\text { solvency }\end{array}$ & $\begin{array}{l}\text { Shareholders equity } \\
\text { (Shareholders equity+Long-term debts) } \\
\text { its obligations to its creditors on account of shareholder equity [68] }\end{array}$ & \\
\hline
\end{tabular}


Table A2. Cont.

\begin{tabular}{|c|c|c|c|}
\hline No. & Variables & Formulas and Description & Category \\
\hline 6 & $\begin{array}{l}\text { Return on } \\
\text { assets }\end{array}$ & $\begin{array}{l}\text { Net income } \\
\text { Total assets, measures the company's ability to make a satisfactory net profit } \\
\text { by using its assets [63] }\end{array}$ & \multirow{5}{*}{ Profitability } \\
\hline 7 & $\begin{array}{l}\text { Return on } \\
\text { equity }\end{array}$ & $\begin{array}{l}\text { Net income } \\
\text { Shareholders equity' measures the return on equity (i.e., the financial } \\
\text { investment which shareholders have made by buying the company's } \\
\text { shares) [62] }\end{array}$ & \\
\hline 8 & $\begin{array}{l}\text { Return on } \\
\text { research capital }\end{array}$ & $\begin{array}{l}\frac{\text { Current year Gross Profit }}{\text { Previous year R\&D Expenditure }}, \text { measures the revenues that a company } \\
\text { generates from R\&D activity [67] }\end{array}$ & \\
\hline 9 & $\begin{array}{l}\text { Operating } \\
\text { profit margin }\end{array}$ & $\begin{array}{l}\text { Operating income } \\
\text { Total revenues } \\
\text { from its operating activity [62] }\end{array}$ & \\
\hline 10 & $\begin{array}{l}\text { Net profit } \\
\text { Margin }\end{array}$ & $\begin{array}{l}\frac{\text { Net income }}{\text { Total revenues }} \text {, measures how much net income is generated as a percentage } \\
\text { of revenues [62] }\end{array}$ & \\
\hline 11 & $\begin{array}{l}\text { Fixed assets } \\
\text { turnover }\end{array}$ & $\begin{array}{l}\text { Total revenues } \\
\text { Fixed assets measures how effectively the company uses its plant and } \\
\text { equipment }[62]\end{array}$ & \multirow{4}{*}{ Assets Management } \\
\hline 12 & $\begin{array}{l}\text { Inventories } \\
\text { turnover }\end{array}$ & $\begin{array}{l}\frac{\text { Total revenues }}{\text { Inventories , measures how many times the particular fixed asset is }} \\
\text { "turned over" during the year [62] }\end{array}$ & \\
\hline 13 & $\begin{array}{l}\text { Total assets } \\
\text { turnover }\end{array}$ & $\frac{\text { Total revenues }}{\text { Total assets }}$, measures the turnover of all of the company's assets [62] & \\
\hline 14 & $\begin{array}{l}\text { Intangible } \\
\text { assets turnover }\end{array}$ & $\begin{array}{l}\text { Total revenues } \\
\text { Intangible assets, measures the effectiveness of intangible assets used in the } \\
\text { company [68] }\end{array}$ & \\
\hline 15 & $\begin{array}{l}\text { Equity } \\
\text { multiplier }\end{array}$ & $\begin{array}{l}\text { Total assets } \\
\text { Shareholders equity, measures the portion of the company's assets that is } \\
\text { financed by stock (rather than debt) [62] }\end{array}$ & \multirow{3}{*}{ Debt Management } \\
\hline 16 & $\begin{array}{l}\text { Debt-to-equity } \\
\quad \text { ratio }\end{array}$ & $\begin{array}{l}\text { Total liabilities } \\
\text { Shareholders equity } \text { measures the degree to which a company is financing its } \\
\text { operations through debt vs. shareholder funds [67] }\end{array}$ & \\
\hline 17 & $\begin{array}{l}\text { Long-term debt } \\
\text { ratio (or } \\
\text { financial } \\
\text { leverage) }\end{array}$ & $\begin{array}{l}\frac{\text { Long-term debts }}{(\text { Shareholders equity+Long-term debts) }}, \text { measures how much of the total funds } \\
\text { to finance the company's wealth are provided by long-term debt [68] }\end{array}$ & \\
\hline 18 & $\mathrm{P} / \mathrm{B}$ ratio & $\begin{array}{l}\text { Market value per share } \\
\text { Book value per share }, \text { measures the market's valuation of a company relative } \\
\text { to its book value }[62]\end{array}$ & \multirow{4}{*}{ Market Value } \\
\hline 19 & $\mathrm{P} / \mathrm{E}$ ratio & $\begin{array}{l}\text { Market value per share } \\
\text { Earnings per share (EPS), measures how much investors are willing to pay per } \\
\text { currency unit of reported profits [62] }\end{array}$ & \\
\hline 20 & Tobin's Q ratio & $\begin{array}{l}\frac{\text { Market value per share }}{\text { Total assets }}, \text { measures whether a company is relatively over- or } \\
\text { under-valued [68] }\end{array}$ & \\
\hline 21 & $\begin{array}{l}\mathrm{EV} / \mathrm{Net} \\
\text { income ratio }\end{array}$ & $\begin{array}{l}\frac{\text { Enterprise value }}{\text { Net income }} \text {, measures the value of a stock that compares a company's } \\
\text { enterprise value to its net income [68] }\end{array}$ & \\
\hline 22 & ESG & $\begin{array}{l}\text { ESG, measures sustainability based on the environmental, social, and } \\
\text { governance pillars [63] }\end{array}$ & Sustainability \\
\hline
\end{tabular}

Source: Author's own representation of formulas and descriptions used in the study $[62,67,68]$. 


\section{Appendix C}

Table A3. Pearson correlation coefficients of the seven variables included in the Z-score function.

\begin{tabular}{|c|c|c|c|c|c|c|c|}
\hline & ROA & $\begin{array}{c}\text { Operating } \\
\text { Profit Margin }\end{array}$ & ESG & $\begin{array}{c}\text { Long-Term } \\
\text { Debt }\end{array}$ & Solvency 2 & $\begin{array}{l}\text { Total Assets } \\
\text { Turnover }\end{array}$ & ROE \\
\hline ROA & 1 & $0.577^{* *(0.000)}$ & $-0.031^{(0.000)}$ & $-0.123^{* *(0.000)}$ & $0.129^{* *}(0.000)$ & $0.440^{* *}(0.000)$ & $0.648^{* *}(0.000)$ \\
\hline $\begin{array}{l}\text { Operating } \\
\text { Profit Margin }\end{array}$ & $0.577^{* *}(0.000)$ & 1 & $0.156^{* *(0.000)}$ & $0.134^{* *}(0.000)$ & $-0.134^{* *(0.000)}$ & $-0.104^{* *(0.000)}$ & $0.485^{* *}(0.000)$ \\
\hline ESG & $-0.031^{(0.000)}$ & $0.156^{* *(0.000)}$ & 1 & $0.241^{* *(0.000)}$ & $-0.236^{* *(0.000)}$ & $0.032^{(0.000)}$ & $0.189^{* *}(0.000)$ \\
\hline $\begin{array}{c}\text { Long-term } \\
\text { debt }\end{array}$ & $-0.123^{* *}(0.000)$ & $0.134^{* *(0.000)}$ & $0.241^{* *(0.000)}$ & 1 & $-1.000^{* *(0.000)}$ & $-0.194^{* *(0.000)}$ & $0.403^{* *}(0.000)$ \\
\hline Solvency 2 & $0.129^{* *}(0.000)$ & $-0.134^{* *}(0.000)$ & $-0.236^{* *}(0.000)$ & $-1.000^{* *(0.000)}$ & 1 & $0.197^{* *}(0.000)$ & $-0.410^{* *(0.000)}$ \\
\hline $\begin{array}{l}\text { Total assets } \\
\text { turnover }\end{array}$ & $0.440^{* *(0.000)}$ & $-0.104^{* *}(0.000)$ & $0.032^{(0.000)}$ & $-0.194^{* *(0.000)}$ & $0.197^{* *}(0.000)$ & 1 & $0.343^{* *(0.000)}$ \\
\hline ROE & $0.648^{* *}(0.000)$ & $0.485^{* *}(0.000)$ & $0.189^{* *}(0.000)$ & $0.403^{* *}(0.000)$ & $-0.410^{* *(0.000)}$ & $0.343^{* *}(.000)$ & 1 \\
\hline
\end{tabular}

** Correlation is significant at the 0.01 level (2-tailed). Source: Author's computation in IBM SPSS.

\section{Appendix D}

Table A4. Z-scores of 100 companies in the pharmaceutical sector, 2020-2011.

\begin{tabular}{|c|c|c|c|c|c|c|c|c|c|c|}
\hline Company Name & 2020 & 2019 & 2018 & 2017 & 2016 & 2015 & 2014 & 2013 & 2012 & 2011 \\
\hline Johnson \& Johnson & 2.94 & 3.07 & 3.06 & 3.04 & 3.17 & 3.08 & 3.19 & 3.01 & 3.00 & 2.94 \\
\hline Pfizer & 2.45 & 2.37 & 2.28 & 2.62 & 2.57 & 2.48 & 2.55 & 2.59 & 2.55 & 2.57 \\
\hline Eli Lilly and Co. & 2.35 & 2.15 & 2.77 & 2.78 & 2.55 & 2.53 & 2.53 & 2.98 & 2.85 & 3.05 \\
\hline Merck \& Co. & 2.96 & 3.18 & 3.17 & 2.92 & 2.92 & 2.74 & 2.79 & 2.55 & 2.84 & 2.94 \\
\hline Abbvie & 1.96 & 1.95 & 2.11 & 2.16 & 2.29 & 1.98 & 1.56 & 1.88 & 1.61 & 2.43 \\
\hline Bristol-Myers Squibb Co. & 2.14 & 2.57 & 3.21 & 3.05 & 2.93 & 2.42 & 2.58 & 2.48 & 2.70 & 3.19 \\
\hline Amgen & 2.35 & 2.70 & 2.68 & 2.77 & 2.92 & 2.79 & 2.57 & 2.32 & 2.36 & 2.39 \\
\hline Novartis & 2.73 & 2.71 & 2.68 & 2.58 & 2.58 & 2.61 & 2.78 & 2.73 & 2.76 & 2.75 \\
\hline Roche Holding & 3.51 & 3.52 & 3.41 & 3.32 & 3.51 & 3.43 & 3.41 & 3.65 & 3.36 & 3.01 \\
\hline AstraZeneca & 2.64 & 2.49 & 2.35 & 2.61 & 2.72 & 2.88 & 2.64 & 2.59 & 3.12 & 3.43 \\
\hline Novo Nordisk & 2.40 & 2.52 & 2.35 & 2.56 & 2.52 & 2.51 & 2.31 & 2.35 & 2.42 & 3.77 \\
\hline Sanofi & 2.74 & 2.54 & 2.50 & 2.58 & 2.56 & 2.60 & 2.60 & 2.58 & 2.61 & 2.47 \\
\hline CSL & 3.32 & 3.42 & 3.34 & 3.06 & 3.13 & 3.63 & 3.45 & 3.40 & 3.24 & 3.24 \\
\hline GlaxoSmithKline & 2.75 & 2.61 & 2.29 & 1.95 & 2.05 & 2.41 & 2.37 & 2.88 & 2.63 & 3.01 \\
\hline Zoetis & 2.57 & 2.49 & 2.33 & 2.09 & 2.12 & 1.65 & 2.13 & 1.39 & 1.92 & 1.81 \\
\hline Otsuka Holdings & 2.49 & 2.41 & 2.07 & 2.03 & 2.02 & 2.05 & 1.83 & 2.20 & 2.20 & 1.71 \\
\hline Chugai Pharmaceutical & 2.23 & 1.95 & 2.48 & 2.40 & 2.31 & 2.49 & 2.50 & 2.54 & 2.53 & 1.57 \\
\hline Bayer & 2.43 & 2.61 & 2.47 & 2.64 & 2.50 & 2.58 & 2.60 & 2.70 & 2.71 & 2.62 \\
\hline Daiichi Sankyo & 2.53 & 2.29 & 2.24 & 2.19 & 2.41 & 2.18 & 2.26 & 2.30 & 2.59 & 2.44 \\
\hline Takeda Pharmaceutical & 2.17 & 2.12 & 2.39 & 2.29 & 2.25 & 2.03 & 2.04 & 2.05 & 2.29 & 2.60 \\
\hline Samsung Biologics & 2.15 & 1.80 & 1.64 & 1.63 & 0.84 & 0.95 & 1.04 & 0.83 & 0.32 & 0.20 \\
\hline Biogen & 3.43 & 3.69 & 3.47 & 3.35 & 3.25 & 3.39 & 3.33 & 3.05 & 3.08 & 3.03 \\
\hline Alexion Pharmaceuticals & 2.69 & 2.72 & 2.07 & 1.82 & 1.80 & 1.71 & 2.75 & 2.44 & 2.51 & 1.51 \\
\hline Astellas Pharma & 2.85 & 3.06 & 2.99 & 3.05 & 3.03 & 2.84 & 2.68 & 2.53 & 1.48 & 1.43 \\
\hline $\begin{array}{l}\text { Changchun High \& New } \\
\text { Technology Industries }\end{array}$ & 2.69 & 2.59 & 2.25 & 2.08 & 1.95 & 2.14 & 2.17 & 2.28 & 2.36 & 1.82 \\
\hline Canopy Growth & 1.06 & 1.10 & 1.14 & 1.01 & 0.99 & 0.85 & 0.05 & 0.09 & 0.32 & 0.20 \\
\hline Ucb & 2.70 & 2.74 & 2.79 & 2.68 & 2.50 & 2.17 & 1.97 & 1.91 & 2.04 & 2.00 \\
\hline Trulieve Cannabis & 2.62 & 2.71 & 1.82 & 1.63 & 0.07 & 0.46 & 0.05 & 0.10 & 0.32 & 0.20 \\
\hline Torrent Pharmaceuticals & 2.61 & 2.30 & 1.69 & 1.96 & 2.79 & 2.07 & 2.37 & 2.26 & 2.15 & 2.15 \\
\hline
\end{tabular}


Table A4. Cont.

\begin{tabular}{|c|c|c|c|c|c|c|c|c|c|c|}
\hline Company Name & 2020 & 2019 & 2018 & 2017 & 2016 & 2015 & 2014 & 2013 & 2012 & 2011 \\
\hline Tilray & 1.09 & 0.76 & 0.51 & 0.12 & 0.57 & 0.46 & 0.05 & 0.09 & 0.32 & 0.20 \\
\hline Teva Pharmaceutical Industries & 2.03 & 2.06 & 2.02 & 2.06 & 2.29 & 2.41 & 2.56 & 2.40 & 2.30 & 2.49 \\
\hline Sun Pharmaceutical Industries & 2.28 & 2.27 & 2.08 & 2.54 & 2.49 & 2.46 & 2.80 & 2.84 & 2.73 & 2.54 \\
\hline Swedish Orphan Biovitrum & 2.65 & 2.69 & 2.96 & 2.45 & 2.30 & 1.56 & 1.16 & 1.07 & 1.05 & 1.04 \\
\hline Dr.Reddy's Laboratories & 2.00 & 2.85 & 2.59 & 2.67 & 3.06 & 3.09 & 3.25 & 3.22 & 3.25 & 3.14 \\
\hline $\begin{array}{l}\text { Recordati Industria Chimica e } \\
\text { Farmaceutica }\end{array}$ & 3.05 & 3.26 & 3.40 & 2.80 & 2.67 & 2.30 & 2.19 & 2.14 & 2.17 & 2.20 \\
\hline Perrigo Company & 2.10 & 2.17 & 2.11 & 2.16 & 2.14 & 1.42 & 1.86 & 2.25 & 2.44 & 2.43 \\
\hline Pacira Biosciences & 2.13 & 1.79 & 1.63 & 1.46 & 1.66 & 0.41 & 0.29 & 1.21 & 1.09 & 0.92 \\
\hline OPKO Health & 1.71 & 1.43 & 1.48 & 1.40 & 1.34 & 0.95 & 0.87 & 0.87 & 0.94 & 0.20 \\
\hline Mckesson & 1.63 & 1.58 & 1.77 & 2.05 & 1.91 & 1.71 & 1.69 & 1.75 & 1.73 & 1.75 \\
\hline Lupin & 2.03 & 2.06 & 2.06 & 2.53 & 2.50 & 2.99 & 3.00 & 2.81 & 2.50 & 2.64 \\
\hline H Lundbeck & 2.26 & 2.35 & 3.04 & 2.89 & 2.44 & 1.94 & 1.91 & 2.31 & 2.35 & 2.70 \\
\hline Kalbe Farma Tbk & 2.84 & 2.91 & 3.00 & 3.09 & 3.14 & 2.97 & 3.03 & 2.04 & 2.01 & 1.59 \\
\hline Jazz Pharmaceuticals & 1.89 & 2.19 & 2.32 & 2.19 & 2.38 & 2.74 & 1.60 & 2.18 & 2.18 & 3.03 \\
\hline Ipsen & 3.01 & 2.52 & 2.87 & 2.68 & 2.68 & 1.68 & 1.58 & 2.57 & 2.36 & 1.79 \\
\hline IPCA Laboratories & 2.55 & 2.02 & 1.77 & 1.76 & 1.59 & 1.82 & 2.48 & 2.37 & 2.34 & 2.34 \\
\hline Horizon Therapeutics & 2.05 & 1.99 & 1.18 & 0.97 & 1.00 & 1.47 & 1.02 & 0.05 & 0.89 & 0.87 \\
\hline Hypera & 2.49 & 1.96 & 2.41 & 2.39 & 2.11 & 1.93 & 2.08 & 2.02 & 1.94 & 1.54 \\
\hline Hikma Pharmaceuticals & 2.81 & 2.73 & 2.62 & 2.29 & 2.34 & 2.73 & 3.00 & 3.03 & 2.45 & 2.40 \\
\hline Green Thumb Industries & 1.79 & 0.96 & 1.08 & 0.08 & 3.00 & 0.46 & 0.05 & 0.09 & 0.32 & 0.20 \\
\hline Luye Pharma Group & 2.25 & 2.47 & 2.29 & 1.12 & 1.10 & 1.03 & 0.97 & 1.01 & 0.90 & 0.84 \\
\hline Dechra Pharmaceuticals & 2.08 & 1.95 & 1.79 & 1.99 & 1.93 & 2.31 & 2.17 & 1.86 & 1.82 & 2.63 \\
\hline Dermapharm Holding & 2.18 & 1.70 & 2.29 & 2.57 & 3.37 & 2.00 & 1.53 & 0.39 & 0.32 & 0.20 \\
\hline Curaleaf Holdings & 1.33 & 1.05 & 0.92 & 0.13 & 0.07 & 0.46 & 0.05 & 0.09 & 0.32 & 0.20 \\
\hline Catalent & 2.03 & 1.77 & 1.54 & 1.54 & 1.22 & 1.41 & 0.57 & 0.61 & 0.49 & 0.51 \\
\hline Cronos Group & 0.09 & 0.38 & 0.51 & 0.91 & 0.07 & 0.86 & 0.05 & 0.09 & 0.32 & 0.20 \\
\hline Cresco Labs & 1.32 & 0.98 & 0.51 & 0.13 & 0.07 & 0.46 & 0.05 & 0.10 & 0.32 & 1.16 \\
\hline Cipla & 2.68 & 2.64 & 2.47 & 2.22 & 2.29 & 2.40 & 2.41 & 2.46 & 2.27 & 2.21 \\
\hline Bausch Health Companies & 1.04 & 1.09 & 0.76 & 1.08 & 0.81 & 1.09 & 1.49 & 0.89 & 1.02 & 1.47 \\
\hline Aurobindo Pharma & 1.63 & 2.55 & 2.64 & 2.88 & 2.75 & 2.72 & 2.59 & 1.81 & 1.57 & 2.08 \\
\hline Aspen Pharmacare & 2.43 & 2.50 & 2.41 & 2.62 & 2.45 & 2.57 & 2.32 & 2.45 & 2.47 & 2.44 \\
\hline Aphria & 1.30 & 1.12 & 0.89 & 0.96 & 0.03 & 0.46 & 0.05 & 0.09 & 0.32 & 0.20 \\
\hline Almirall & 1.91 & 1.87 & 1.65 & 1.04 & 1.27 & 1.42 & 1.61 & 1.14 & 0.53 & 0.65 \\
\hline ALK-Abello & 2.03 & 1.69 & 1.28 & 1.32 & 1.78 & 1.75 & 1.77 & 1.52 & 1.57 & 1.78 \\
\hline Alembic Pharmaceuticals & 2.30 & 2.20 & 2.08 & 1.50 & 2.28 & 2.67 & 3.03 & 2.73 & 2.60 & 2.51 \\
\hline Abbott Laboratories & 2.64 & 2.49 & 2.43 & 2.31 & 2.37 & 2.48 & 2.46 & 2.47 & 2.36 & 2.26 \\
\hline Abcam & 1.06 & 1.60 & 1.80 & 1.13 & 1.12 & 1.29 & 1.40 & 1.43 & 1.39 & 2.06 \\
\hline Tasly Pharmaceutical & 2.07 & 2.01 & 2.05 & 1.92 & 2.10 & 2.29 & 2.32 & 2.30 & 2.11 & 1.98 \\
\hline Zhejiang Hisun Pharmaceutical & 1.56 & 1.28 & 1.44 & 1.49 & 1.39 & 1.23 & 1.53 & 1.58 & 1.43 & 1.72 \\
\hline Shanghai Fosun Pharmaceutical & 2.26 & 2.19 & 2.10 & 2.14 & 2.19 & 2.05 & 1.48 & 1.49 & 1.41 & 1.35 \\
\hline Sawai Group & 1.63 & 1.64 & 1.56 & 1.85 & 1.89 & 1.93 & 1.93 & 2.03 & 1.91 & 2.00 \\
\hline Humanwell Healthcare & 1.67 & 1.42 & 1.63 & 1.53 & 1.61 & 1.71 & 1.79 & 1.85 & 1.80 & 1.78 \\
\hline Oneness Biotech & 0.13 & 0.42 & 0.51 & 0.13 & 0.07 & 0.46 & 0.08 & 0.17 & 0.32 & 0.20 \\
\hline Taisho Pharmaceutical Holdings & 0.81 & 1.02 & 1.02 & 1.00 & 0.79 & 0.68 & 0.83 & 0.72 & 0.74 & 0.20 \\
\hline JCR Pharmaceuticals & 1.63 & 1.90 & 1.82 & 1.60 & 1.58 & 1.57 & 1.48 & 1.39 & 1.39 & 1.47 \\
\hline Santen Pharmaceutical & 2.38 & 2.47 & 2.51 & 1.42 & 3.07 & 2.29 & 2.40 & 1.38 & 1.45 & 1.64 \\
\hline Hisamitsu Pharmaceutical & 1.72 & 2.01 & 1.98 & 1.99 & 2.07 & 1.99 & 1.90 & 1.95 & 2.22 & 2.29 \\
\hline Ono Pharmaceutical & 1.81 & 2.68 & 2.54 & 2.68 & 2.24 & 1.93 & 2.17 & 2.20 & 2.08 & 2.13 \\
\hline Eisai & 2.92 & 2.66 & 2.61 & 2.49 & 2.49 & 2.25 & 2.42 & 2.43 & 2.75 & 2.71 \\
\hline Shionogi \& Co. & 3.20 & 2.26 & 3.08 & 2.86 & 2.62 & 2.18 & 2.28 & 2.41 & 2.23 & 2.27 \\
\hline Sumitomo Dainippon Pharma & 2.20 & 2.30 & 2.40 & 2.18 & 2.10 & 2.06 & 2.21 & 1.90 & 1.88 & 1.95 \\
\hline Kyowa Kirin & 1.38 & 2.19 & 2.20 & 2.23 & 2.22 & 1.20 & 1.03 & 1.07 & 1.15 & 2.05 \\
\hline China Resources Pharmaceutical & 2.31 & 2.45 & 2.55 & 1.95 & 2.03 & 2.09 & 2.15 & 2.11 & 0.32 & 0.20 \\
\hline
\end{tabular}


Table A4. Cont.

\begin{tabular}{|c|c|c|c|c|c|c|c|c|c|c|}
\hline Company Name & 2020 & 2019 & 2018 & 2017 & 2016 & 2015 & 2014 & 2013 & 2012 & 2011 \\
\hline Porton Pharma Solutions & 1.73 & 1.49 & 1.30 & 1.55 & 1.70 & 1.57 & 1.75 & 2.13 & 2.16 & 2.21 \\
\hline Anhui Anke Biotechnology & 0.96 & 1.75 & 2.01 & 2.11 & 1.93 & 0.88 & 1.04 & 1.02 & 0.93 & 0.77 \\
\hline Zhejiang Starry Pharmaceutical & 1.92 & 1.57 & 1.57 & 1.55 & 1.85 & 1.78 & 1.84 & 1.72 & 0.32 & 0.20 \\
\hline Sino Biopharmaceutical & 2.53 & 2.62 & 2.50 & 2.65 & 2.48 & 2.66 & 2.69 & 1.52 & 2.63 & 2.28 \\
\hline Virbac & 2.78 & 2.25 & 1.68 & 1.51 & 1.60 & 1.32 & 1.75 & 2.00 & 2.02 & 2.22 \\
\hline $\begin{array}{c}\text { Guangzhou Baiyunshan } \\
\text { Pharmaceutical }\end{array}$ & 2.67 & 2.57 & 1.46 & 2.25 & 2.14 & 1.25 & 2.30 & 1.18 & 0.93 & 0.85 \\
\hline China Traditional Chinese Medicine & 2.17 & 2.11 & 2.17 & 1.65 & 1.57 & 1.39 & 1.84 & 1.50 & 1.10 & 0.65 \\
\hline $\begin{array}{c}\text { China Grand Pharmaceutical and } \\
\text { Healthcare }\end{array}$ & 1.98 & 1.84 & 1.64 & 1.81 & 1.64 & 1.64 & 1.67 & 1.64 & 1.58 & 1.64 \\
\hline Sihuan Pharmaceutical Holdings & 2.06 & 2.41 & 1.73 & 0.62 & 0.59 & 1.60 & 1.64 & 1.56 & 2.14 & 2.12 \\
\hline Green Cross & 1.56 & 1.42 & 1.55 & 1.64 & 1.67 & 1.76 & 1.77 & 1.80 & 1.82 & 1.92 \\
\hline Shenzhen Hepalink Pharmaceutical & 1.88 & 1.59 & 1.63 & 1.12 & 1.31 & 1.51 & 1.27 & 0.25 & 0.72 & 0.71 \\
\hline Shenzhen Salubris Pharmaceuticals & 1.73 & 2.17 & 2.75 & 2.62 & 2.66 & 2.77 & 1.71 & 1.73 & 1.63 & 1.30 \\
\hline Jiangsu Nhwa Pharmaceutical & 2.25 & 2.34 & 2.22 & 2.19 & 2.12 & 2.16 & 2.40 & 2.46 & 2.47 & 2.39 \\
\hline Yifan Pharmaceutical & 2.00 & 1.85 & 1.79 & 2.33 & 2.03 & 1.77 & 0.76 & 1.95 & 0.33 & 0.15 \\
\hline $\begin{array}{c}\text { China Resources Sanjiu Medical \& } \\
\text { Pharmaceutical }\end{array}$ & 1.23 & 1.24 & 1.21 & 2.11 & 1.87 & 1.95 & 1.96 & 2.09 & 2.17 & 2.02 \\
\hline Apeloa Pharmaceutical & 1.51 & 1.13 & 1.03 & 0.87 & 1.74 & 1.68 & 1.83 & 1.69 & 1.73 & 1.60 \\
\hline Jilin Aodong Pharmaceutical & 1.52 & 1.23 & 1.24 & 0.42 & 0.38 & 0.51 & 0.51 & 0.38 & 0.27 & 0.54 \\
\hline Yunnan Baiyao & 2.26 & 2.11 & 2.13 & 2.10 & 2.16 & 2.36 & 2.44 & 2.53 & 2.49 & 2.41 \\
\hline
\end{tabular}

Source: Author's computation in Excel.

Table A5. Normalized Z-scores of 100 companies in the pharmaceutical sector, 2020-2011.

\begin{tabular}{|c|c|c|c|c|c|c|c|c|c|c|}
\hline Company Name & 2020 & 2019 & 2018 & 2017 & 2016 & 2015 & 2014 & 2013 & 2012 & 2011 \\
\hline Johnson \& Johnson & 83.66 & 82.05 & 86.97 & 90.94 & 89.91 & 82.48 & 91.58 & 81.42 & 85.18 & 77.66 \\
\hline Pfizer & 70.36 & 62.96 & 62.14 & 79.15 & 74.03 & 65.57 & 74.43 & 71.15 & 72.31 & 68.13 \\
\hline Eli Lilly and Co. & 66.67 & 55.52 & 79.59 & 85.58 & 74.23 & 67.41 & 74.22 & 81.44 & 82.21 & 81.60 \\
\hline Merck \& Co. & 84.68 & 86.10 & 90.20 & 86.80 & 82.54 & 72.28 & 81.60 & 69.67 & 80.25 & 76.98 \\
\hline Abbvie & 60.36 & 50.56 & 56.38 & 65.08 & 78.41 & 51.28 & 48.11 & 61.65 & 45.97 & 66.59 \\
\hline Bristol-Myers Squibb Co. & 61.33 & 67.21 & 92.71 & 92.30 & 84.49 & 64.09 & 75.34 & 68.77 & 77.30 & 84.97 \\
\hline Amgen & 66.82 & 78.13 & 73.19 & 84.77 & 83.92 & 75.25 & 75.69 & 65.45 & 68.67 & 64.84 \\
\hline Novartis & 77.61 & 71.35 & 75.00 & 77.21 & 73.86 & 68.75 & 80.44 & 74.17 & 78.43 & 72.79 \\
\hline Roche Holding & 100 & 95.28 & 98.66 & 99.46 & 100 & 94.01 & 99.74 & 100 & 100 & 85.10 \\
\hline AstraZeneca & 76.10 & 65.24 & 65.43 & 78.54 & 78.73 & 76.45 & 76.11 & 70.67 & 89.31 & 91.50 \\
\hline Novo Nordisk & 74.68 & 72.10 & 63.51 & 83.85 & 79.88 & 73.07 & 73.63 & 69.51 & 73.43 & 100 \\
\hline Sanofi & 78.49 & 66.22 & 68.48 & 76.84 & 73.25 & 68.28 & 75.20 & 70.17 & 73.72 & 65.59 \\
\hline CSL & 94.29 & 92.10 & 97.17 & 93.51 & 91.29 & 100 & 100 & 92.47 & 92.82 & 85.38 \\
\hline GlaxoSmithKline & 81.06 & 72.35 & 61.71 & 59.61 & 69.35 & 62.69 & 75.39 & 84.08 & 73.39 & 83.90 \\
\hline Zoetis & 76.52 & 69.96 & 70.15 & 69.69 & 67.18 & 46.03 & 67.10 & 46.54 & 55.37 & 49.82 \\
\hline Otsuka Holdings & 71.07 & 63.11 & 55.97 & 62.41 & 59.63 & 53.75 & 55.96 & 61.32 & 62.72 & 47.58 \\
\hline Chugai Pharmaceutical & 65.89 & 52.45 & 68.71 & 72.64 & 67.26 & 65.69 & 72.86 & 69.31 & 71.73 & 44.20 \\
\hline Bayer & 68.77 & 67.99 & 67.37 & 78.88 & 72.26 & 68.69 & 76.04 & 73.73 & 76.87 & 69.62 \\
\hline Daiichi Sankyo & 72.11 & 60.03 & 60.77 & 66.36 & 69.51 & 56.77 & 66.51 & 63.61 & 73.36 & 65.01 \\
\hline Takeda Pharmaceutical & 62.37 & 55.22 & 65.82 & 69.21 & 65.22 & 52.50 & 60.61 & 57.61 & 64.87 & 68.97 \\
\hline Samsung Biologics & 62.27 & 47.08 & 43.32 & 51.14 & 30.13 & 31.39 & 35.14 & 28.44 & 11.32 & 11.17 \\
\hline Biogen & 97.49 & 100 & 100 & 100 & 92.66 & 92.43 & 95.56 & 82.63 & 87.67 & 79.96 \\
\hline Alexion Pharmaceuticals & 75.87 & 72.56 & 55.39 & 56.73 & 54.30 & 44.35 & 80.26 & 67.15 & 71.62 & 43.63 \\
\hline Astellas Pharma & 80.73 & 80.84 & 83.54 & 90.43 & 85.71 & 74.85 & 77.22 & 68.92 & 43.33 & 40.77 \\
\hline $\begin{array}{l}\text { Changchun High \& New } \\
\text { Technology Industries }\end{array}$ & 78.16 & 69.98 & 63.81 & 65.22 & 59.22 & 58.64 & 66.71 & 65.70 & 70.81 & 52.04 \\
\hline
\end{tabular}


Table A5. Cont.

\begin{tabular}{|c|c|c|c|c|c|c|c|c|c|c|}
\hline Company Name & 2020 & 2019 & 2018 & 2017 & 2016 & 2015 & 2014 & 2013 & 2012 & 2011 \\
\hline Canopy Growth & 34.38 & 28.64 & 28.27 & 34.57 & 33.73 & 21.61 & 10.06 & 11.02 & 11.32 & 11.17 \\
\hline Ucb & 75.53 & 70.89 & 76.16 & 78.88 & 70.99 & 56.27 & 58.62 & 53.69 & 57.46 & 53.74 \\
\hline Trulieve Cannabis & 73.40 & 69.95 & 47.96 & 51.16 & 11.08 & 11.34 & 10.00 & 11.30 & 11.32 & 11.17 \\
\hline Torrent Pharmaceuticals & 73.25 & 59.53 & 44.32 & 59.91 & 78.28 & 53.76 & 68.61 & 62.06 & 60.49 & 57.17 \\
\hline Tilray & 35.12 & 19.79 & 10.00 & 10.88 & 23.50 & 11.34 & 10.06 & 11.02 & 11.32 & 11.17 \\
\hline Teva Pharmaceutical Industries & 58.76 & 53.26 & 53.87 & 62.50 & 65.80 & 62.68 & 73.36 & 65.33 & 64.57 & 65.32 \\
\hline Sun Pharmaceutical Industries & 64.97 & 58.59 & 55.54 & 75.24 & 70.94 & 63.95 & 79.35 & 75.50 & 75.99 & 66.52 \\
\hline Swedish Orphan Biovitrum & 74.29 & 69.56 & 81.09 & 72.86 & 66.14 & 40.25 & 38.13 & 34.12 & 30.96 & 31.12 \\
\hline Dr. Reddy's Laboratories & 57.85 & 73.68 & 70.46 & 78.51 & 84.84 & 80.48 & 90.73 & 84.60 & 90.07 & 80.74 \\
\hline $\begin{array}{l}\text { Recordati Industria Chimica e } \\
\text { Farmaceutica }\end{array}$ & 84.27 & 84.21 & 93.95 & 81.97 & 75.23 & 59.72 & 64.19 & 59.14 & 60.89 & 58.36 \\
\hline Perrigo Company & 60.54 & 56.05 & 56.60 & 65.03 & 62.25 & 36.59 & 55.78 & 61.84 & 68.16 & 64.02 \\
\hline Pacira Biosciences & 61.15 & 46.39 & 42.57 & 46.61 & 50.21 & 10.00 & 16.18 & 37.25 & 31.89 & 28.21 \\
\hline OPKO Health & 50.56 & 36.91 & 38.23 & 44.82 & 42.49 & 24.21 & 30.72 & 29.24 & 27.96 & 11.17 \\
\hline Mckesson & 48.63 & 40.78 & 46.65 & 62.11 & 56.44 & 44.12 & 51.34 & 49.90 & 49.14 & 47.89 \\
\hline Lupin & 58.77 & 53.35 & 55.07 & 74.97 & 70.97 & 77.83 & 84.42 & 74.95 & 70.01 & 68.94 \\
\hline H Lundbeck & 64.55 & 60.82 & 83.54 & 84.41 & 69.53 & 50.32 & 57.01 & 63.20 & 65.79 & 70.18 \\
\hline Kalbe Farma Tbk & 78.90 & 75.33 & 82.33 & 89.65 & 86.84 & 77.41 & 85.36 & 56.74 & 56.61 & 44.13 \\
\hline Jazz Pharmaceuticals & 55.21 & 56.63 & 62.66 & 65.86 & 68.01 & 71.18 & 49.30 & 60.17 & 61.19 & 78.03 \\
\hline Ipsen & 83.38 & 65.27 & 78.69 & 78.96 & 75.51 & 43.36 & 48.59 & 69.19 & 66.09 & 48.69 \\
\hline IPCA Laboratories & 71.77 & 52.14 & 46.69 & 54.42 & 48.48 & 47.16 & 71.33 & 64.48 & 65.59 & 61.86 \\
\hline Horizon Therapeutics & 59.27 & 51.38 & 29.42 & 33.43 & 34.02 & 37.85 & 34.57 & 10.00 & 26.58 & 26.92 \\
\hline Hypera & 70.27 & 50.74 & 65.25 & 71.08 & 61.39 & 49.93 & 61.33 & 56.40 & 54.92 & 42.92 \\
\hline Hikma Pharmaceuticals & 78.13 & 70.47 & 71.31 & 68.42 & 67.18 & 71.09 & 84.48 & 80.06 & 68.58 & 63.30 \\
\hline Green Thumb Industries & 52.71 & 24.85 & 26.50 & 10.00 & 83.46 & 11.34 & 10.06 & 11.02 & 11.32 & 11.17 \\
\hline Luye Pharma Group & 64.08 & 63.88 & 61.84 & 37.56 & 36.45 & 26.28 & 33.19 & 32.70 & 26.87 & 26.22 \\
\hline Dechra Pharmaceuticals & 59.92 & 50.51 & 47.08 & 60.61 & 57.02 & 59.85 & 63.63 & 52.47 & 51.53 & 68.61 \\
\hline Dermapharm Holding & 62.48 & 44.06 & 61.58 & 75.98 & 92.60 & 51.87 & 47.50 & 17.98 & 11.32 & 11.17 \\
\hline Curaleaf Holdings & 41.07 & 27.17 & 21.87 & 11.26 & 11.08 & 11.34 & 10.06 & 11.02 & 11.32 & 11.17 \\
\hline Catalent & 58.70 & 45.83 & 39.97 & 48.77 & 39.42 & 36.27 & 23.24 & 23.30 & 15.96 & 18.54 \\
\hline Cronos Group & 10.00 & 10.00 & 10.01 & 31.88 & 11.08 & 21.74 & 10.06 & 11.02 & 11.32 & 11.17 \\
\hline Cresco Labs & 40.85 & 25.32 & 10.01 & 11.26 & 11.08 & 11.34 & 10.06 & 11.14 & 11.32 & 33.78 \\
\hline Cipla & 74.89 & 68.15 & 66.92 & 66.58 & 65.86 & 62.36 & 69.63 & 66.76 & 63.63 & 58.73 \\
\hline Bausch Health Companies & 33.82 & 28.23 & 17.28 & 36.51 & 29.24 & 27.89 & 46.39 & 29.69 & 30.09 & 41.32 \\
\hline Aurobindo Pharma & 48.57 & 65.94 & 71.78 & 84.07 & 77.23 & 70.65 & 74.20 & 51.33 & 44.82 & 55.72 \\
\hline Aspen Pharmacare & 68.71 & 64.69 & 65.29 & 77.20 & 69.77 & 66.73 & 67.34 & 66.53 & 69.15 & 64.07 \\
\hline Aphria & 40.33 & 29.02 & 21.17 & 33.32 & 10.00 & 11.34 & 10.06 & 11.02 & 11.32 & 11.17 \\
\hline Almirall & 55.73 & 48.28 & 42.99 & 35.46 & 40.58 & 36.50 & 49.39 & 35.59 & 16.98 & 21.79 \\
\hline ALK-Abello & 58.75 & 43.84 & 32.44 & 42.84 & 53.31 & 45.13 & 53.52 & 44.53 & 44.85 & 48.60 \\
\hline Alembic Pharmaceuticals & 65.43 & 56.94 & 55.57 & 47.48 & 65.52 & 69.27 & 85.24 & 73.10 & 72.63 & 65.88 \\
\hline Abbott Laboratories & 74.02 & 64.39 & 65.91 & 69.07 & 67.76 & 64.39 & 70.83 & 66.86 & 66.17 & 59.86 \\
\hline Abcam & 34.45 & 41.32 & 47.53 & 37.74 & 36.96 & 33.25 & 44.20 & 42.36 & 40.11 & 55.20 \\
\hline Tasly Pharmaceutical & 59.57 & 51.98 & 54.61 & 58.76 & 61.16 & 59.37 & 67.39 & 62.87 & 59.34 & 53.31 \\
\hline Zhejiang Hisun Pharmaceutical & 46.97 & 33.10 & 36.99 & 47.41 & 43.77 & 31.57 & 47.47 & 46.08 & 41.09 & 47.18 \\
\hline Shanghai Fosun Pharmaceutical & 64.58 & 56.71 & 56.13 & 64.68 & 63.33 & 53.14 & 46.05 & 43.80 & 40.57 & 38.27 \\
\hline Sawai Group & 48.60 & 42.40 & 40.57 & 56.95 & 56.08 & 50.08 & 57.55 & 56.52 & 54.04 & 53.78 \\
\hline Humanwell Healthcare & 49.71 & 36.74 & 42.52 & 48.37 & 49.02 & 44.07 & 53.92 & 52.38 & 51.03 & 48.62 \\
\hline Oneness Biotech & 11.04 & 10.99 & 10.01 & 11.26 & 11.08 & 11.34 & 10.83 & 12.87 & 11.32 & 11.17 \\
\hline Taisho Pharmaceutical Holdings & 28.17 & 26.37 & 24.78 & 34.22 & 28.70 & 17.05 & 29.69 & 25.81 & 22.53 & 11.17 \\
\hline JCR Pharmaceuticals & 48.77 & 49.23 & 47.97 & 50.20 & 48.33 & 40.48 & 46.16 & 41.52 & 39.93 & 41.15 \\
\hline Santen Pharmaceutical & 67.54 & 63.82 & 68.13 & 45.48 & 85.07 & 59.34 & 69.46 & 41.24 & 41.74 & 45.13 \\
\hline Hisamitsu Pharmaceutical & 50.81 & 52.01 & 52.61 & 60.59 & 60.55 & 51.56 & 56.69 & 54.62 & 62.45 & 60.57 \\
\hline Ono Pharmaceutical & 53.14 & 69.40 & 69.04 & 78.78 & 64.53 & 50.03 & 63.58 & 60.54 & 58.65 & 56.77 \\
\hline Eisai & 81.00 & 68.68 & 70.91 & 73.91 & 70.72 & 58.31 & 69.82 & 66.05 & 76.54 & 70.48 \\
\hline Shionogi \& Co. & 87.98 & 58.46 & 84.79 & 83.71 & 73.96 & 56.48 & 66.43 & 65.59 & 62.57 & 60.03 \\
\hline Sumitomo Dainippon Pharma & 63.05 & 59.58 & 64.90 & 65.62 & 61.23 & 53.43 & 64.64 & 53.45 & 53.24 & 52.52 \\
\hline
\end{tabular}


Table A5. Cont.

\begin{tabular}{|c|c|c|c|c|c|c|c|c|c|c|}
\hline Company Name & 2020 & 2019 & 2018 & 2017 & 2016 & 2015 & 2014 & 2013 & 2012 & 2011 \\
\hline Kyowa Kirin & 42.33 & 56.53 & 59.25 & 66.92 & 64.24 & 30.69 & 34.83 & 33.98 & 33.73 & 54.83 \\
\hline China Resources Pharmaceutical & 65.79 & 63.34 & 69.27 & 59.65 & 59.46 & 54.10 & 63.19 & 58.37 & 11.32 & 11.17 \\
\hline Porton Pharma Solutions & 51.15 & 38.52 & 32.91 & 48.92 & 51.32 & 40.56 & 53.03 & 58.84 & 60.72 & 58.68 \\
\hline Anhui Anke Biotechnology & 31.76 & 45.36 & 53.52 & 63.71 & 57.06 & 22.32 & 34.95 & 32.92 & 27.58 & 24.55 \\
\hline Zhejiang Starry Pharmaceutical & 55.81 & 40.75 & 40.66 & 49.05 & 55.03 & 46.15 & 55.24 & 49.24 & 11.32 & 11.17 \\
\hline Sino Biopharmaceutical & 71.28 & 67.72 & 67.96 & 78.17 & 70.69 & 69.11 & 76.64 & 44.52 & 73.39 & 60.27 \\
\hline Virbac & 77.45 & 58.10 & 44.07 & 47.99 & 48.84 & 33.94 & 52.99 & 55.91 & 57.05 & 59.00 \\
\hline $\begin{array}{l}\text { Guangzhou Baiyunshan } \\
\text { Pharmaceutical }\end{array}$ & 74.83 & 66.33 & 37.52 & 67.55 & 62.21 & 31.97 & 66.73 & 36.51 & 27.60 & 26.50 \\
\hline China Traditional Chinese Medicine & 62.22 & 54.53 & 58.31 & 51.60 & 48.14 & 35.83 & 55.30 & 44.21 & 32.17 & 21.85 \\
\hline $\begin{array}{c}\text { China Grand Pharmaceutical and } \\
\text { Healthcare }\end{array}$ & 57.48 & 47.49 & 42.91 & 55.80 & 49.75 & 42.30 & 50.92 & 47.39 & 45.11 & 45.25 \\
\hline Sihuan Pharmaceutical Holdings & 59.36 & 62.35 & 45.37 & 24.36 & 23.97 & 41.34 & 50.09 & 45.44 & 60.28 & 56.65 \\
\hline Green Cross & 46.80 & 36.65 & 40.28 & 51.32 & 50.53 & 45.44 & 53.45 & 51.12 & 51.71 & 51.80 \\
\hline Shenzhen Hepalink Pharmaceutical & 54.94 & 41.17 & 42.59 & 37.59 & 41.73 & 38.88 & 40.87 & 14.77 & 22.01 & 23.22 \\
\hline Shenzhen Salubris Pharmaceuticals & 51.19 & 56.04 & 75.11 & 77.39 & 75.12 & 72.03 & 52.02 & 49.44 & 46.39 & 37.17 \\
\hline Jiangsu Nhwa Pharmaceutical & 64.16 & 60.59 & 59.82 & 65.88 & 61.61 & 56.05 & 69.40 & 66.71 & 68.98 & 62.92 \\
\hline Yifan Pharmaceutical & 57.97 & 47.95 & 47.30 & 69.57 & 59.57 & 45.76 & 28.03 & 54.67 & 11.54 & 10.00 \\
\hline $\begin{array}{c}\text { China Resources Sanjiu Medical \& } \\
\text { Pharmaceutical }\end{array}$ & 38.51 & 32.09 & 30.26 & 63.89 & 55.52 & 50.44 & 58.33 & 57.86 & 60.89 & 54.28 \\
\hline Apeloa Pharmaceutical & 45.71 & 29.24 & 25.06 & 30.87 & 52.37 & 43.39 & 55.02 & 48.68 & 49.21 & 44.20 \\
\hline Jilin Aodong Pharmaceutical & 45.89 & 31.86 & 31.29 & 18.92 & 18.73 & 12.73 & 21.58 & 17.71 & 10.00 & 19.19 \\
\hline Yunnan Baiyao & 64.33 & 54.54 & 57.12 & 63.57 & 62.64 & 61.15 & 70.35 & 68.32 & 69.73 & 63.54 \\
\hline
\end{tabular}

\section{References}

1. Gomes, E.; Angwin, D.N.; Weber, Y.; Yedidia Tarba, S. Critical success factors through the mergers and acquisitions process: Revealing pre-and post-M\&A connections for improved performance. Thunderbird Int. Bus. Rev. 2013, 55, $13-35$.

2. Institute for Mergers, Acquisitions and Alliances (IMAA). Available online: https://imaa-institute.org/mergers-and-acquisitionsstatistics / (accessed on 15 March 2021).

3. Christensen, C.M.; Alton, R.; Rising, C.; Waldeck, A. The new M\&A playbook. Harv. Bus. Rev. 2011, 89, 48-57.

4. Straub, T. Reasons for Frequent Failure in Mergers and Acquisitions: A Comprehensive Analysis; Deutscher Universitätsverlag: Wiesbaden, Germany, 2007.

5. Wang, D.; Moini, H. Performance assessment of mergers and acquisitions: Evidence from Denmark. E-Leader Berlin. 2012, pp. 1-15. Available online: http:/ / www.g-casa.com/PaperDatabase.htm (accessed on 10 March 2021).

6. Pacquisitions Blog: What Happens When I Change My Mind (and Don't Complete the Transaction)? Available online: https: / / pacquisitions.wordpress.com/2014/08/14/what-happenswhen-i-change-my-mind-and-dont-complete-the-transaction/ (accessed on 16 March 2021).

7. Rao-Nicholson, R.; Salaber, J.; Cao, T.H. Long-term performance of mergers and acquisitions in ASEAN countries. Res. Int. Bus. Financ. 2016, 36, 373-387. [CrossRef]

8. Liargovas, P.; Repousis, S. The impact of mergers and acquisitions on the performance of the Greek banking sector: An event study approach. Int. J. Econ. Financ. 2011, 3, 89-100. [CrossRef]

9. Grigorieva, S.; Petrunina, T. The performance of mergers and acquisitions in emerging capital markets: New angle. J. Manag. Control 2015, 26, 377-403. [CrossRef]

10. Calipha, R.; Tarba, S.; Brock, D. Mergers and acquisitions: A review of phases, motives, and success factors. In Advances in Mergers and Acquisitions; Emerald Group Publishing Limited: Bingley, UK, 2010.

11. Wang, Q.; Lau, R.Y.; Yang, K. Does the interplay between the personality traits of CEOs and CFOs influence corporate mergers and acquisitions intensity? An econometric analysis with machine learning-based constructs. Decis. Support Syst. 2020, 139, 113424. [CrossRef]

12. Hu, X.; Yin, X.; Jin, Z.; Li, J. How Do International M\&As Affect Rival Firm's Sustainable Performance?-Empirical Evidence from an Emerging Market. Sustainability 2020, 12, 1318.

13. Cloodt, M.; Hagedoorn, J.; Van Kranenburg, H. Mergers and acquisitions: Their effect on the innovative performance of companies in high-tech industries. Res. Policy 2006, 35, 642-654. [CrossRef]

14. Hagedoorn, J.; Duysters, G. The effect of mergers and acquisitions on the technological performance of companies in a high-tech environment. Technol. Anal. Strateg. Manag. 2002, 14, 67-85. [CrossRef]

15. Zhang, W.; Wang, K.; Li, L.; Chen, Y.; Wang, X. The impact of firms' mergers and acquisitions on their performance in emerging economies. Technol. Forecast. Soc. Chang. 2018, 135, 208-216. [CrossRef] 
16. Hassan, M.; Patro, D.K.; Tuckman, H.; Wang, X. Do mergers and acquisitions create shareholder wealth in the pharmaceutical industry? Int. J. Pharm. Healthc. Mark. 2007, 1, 58-78. [CrossRef]

17. Danzon, P.M.; Epstein, A.; Nicholson, S. Mergers and acquisitions in the pharmaceutical and biotech industries. Manag. Decis. Econ. 2007, 28, 307-328. [CrossRef]

18. Patel, R. Pre \& post-merger financial performance: An Indian perspective. J. Cent. Bank. Theory Pract. 2018, 7, 181-200.

19. Rani, N.; Yadav, S.S.; Jain, P. Post-M\&A operating performance of Indian acquiring firms: A Du Pont analysis. Int. J. Econ. Financ. 2013, 5, 65.

20. Rani, N.; Yadav, S.S.; Jain, P. Financial performance analysis of mergers and acquisitions: Evidence from India. Int. J. Commer. Manag. 2015, 25, 402-423. [CrossRef]

21. Martynova, M.; Oosting, S.; Renneboog, L. The long-term operating performance in European mergers and acquisitions. In International Mergers and Acquisitions Activity Since 1990; Elsevier: Amsterdam, The Netherlands, 2007; pp. 79-116.

22. Borodin, A.; Sayabek, Z.S.; Islyam, G.; Panaedova, G. Impact of mergers and acquisitions on companies' financial performance. J. Int. Stud. 2020, 13, 34-47. [CrossRef] [PubMed]

23. Chen, J.; Zhao, X.; Niu, X.; Fan, Y.H.; Taylor, G. Does M\&A Financing Affect Firm Performance under Different Ownership Types? Sustainability 2020, 12, 3078.

24. Kwon, J.; Kim, C.; Lee, K.C. Moderating Effect of the Continental Factor on the Business Strategy and M\&A Performance in the Pharmaceutical Industry for Sustainable International Business. Sustainability 2020, 12, 4985.

25. Weber, Y.; Tarba, S.Y.; Reichel, A. A model of the influence of culture on integration approaches and international mergers and acquisitions performance. Int. Stud. Manag. Organ. 2011, 41, 9-24. [CrossRef]

26. Rottig, D.; Reus, T.H.; Tarba, S.Y. The impact of culture on mergers and acquisitions: A third of a century of research. In Advances in Mergers and Acquisitions; Emerald Group Publishing Limited: Bingley, UK, 2014.

27. Weber, Y.; Tarba, S.Y.; Bachar, Z.R. Mergers and acquisitions performance paradox: The mediating role of integration approach Eur. J. Int. Manag. 2011, 5, 373-393. [CrossRef]

28. Nagasha, S.; Bananuka, J.; Musimenta, D.; Lulu, G. The Impact of Merger and Acquisition on Firm Performance in East Africa; Services for Science and Education: Birmingham, UK, 2017.

29. Dickerson, A.P.; Gibson, H.D.; Tsakalotos, E. The impact of acquisitions on company performance: Evidence from a large panel of UK firms. Oxf. Econ. Pap. 1997, 49, 344-361. [CrossRef]

30. Mihaiu, D.M. Financial Synergies of Mergers and Acquisitions: Between Intentions and Achievements. In Emerging Issues in the Global Economy; Springer: New York, NY, USA, 2018; pp. 237-252.

31. Pillania, R.K.; Kumar, S.; Bansal, L.K. The impact of mergers and acquisitions on corporate performance in India. Manag. Decis. 2008, 46, 1531-1543.

32. Srivastava, R. Managing mergers and acquisitions in health care: A case study in the pharmaceutical sector. Int. J. Healthc. Manag. 2020, 13 (Suppl. 1), 61-73. [CrossRef]

33. Paniagua, J.; Rivelles, R.; Sapena, J. Corporate governance and financial performance: The role of ownership and board structure. J. Bus. Res. 2018, 89, 229-234. [CrossRef]

34. Alshehhi, A.; Nobanee, H.; Khare, N. The impact of sustainability practices on corporate financial performance: Literature trends and future research potential. Sustainability 2018, 10, 494. [CrossRef]

35. Barauskaite, G.; Streimikiene, D. Corporate social responsibility and financial performance of companies: The puzzle of concepts, definitions and assessment methods. Corp. Soc. Responsib. Environ. Manag. 2021, 28, 278-287. [CrossRef]

36. Orlitzky, M.; Schmidt, F.L.; Rynes, S.L. Corporate social and financial performance: A meta-analysis. Organ. Stud. 2003, 24, 403-441. [CrossRef]

37. Lahouel, B.B.; Zaied, Y.B.; Song, Y.; Yang, G.-L. Corporate social performance and financial performance relationship: A data envelopment analysis approach without explicit input. Financ. Res. Lett. 2021, 39, 101656. [CrossRef]

38. Cho, S.Y.; Lee, C. Managerial efficiency, corporate social performance, and corporate financial performance. J. Bus. Ethics 2019, 158, 467-486. [CrossRef]

39. Bacidore, J.M.; Boquist, J.A.; Milbourn, T.T.; Thakor, A.V. The search for the best financial performance measure. Financ. Anal. J. 1997, 53, 11-20. [CrossRef]

40. Ferguson, R.; Leistikow, D. Search for the best financial performance measure: Basics are better. Financ. Anal. J. 1998, 54, 81-85. [CrossRef]

41. Galant, A.; Cadez, S. Corporate social responsibility and financial performance relationship: A review of measurement approaches. Econ. Res. Ekon. Istraživanja 2017, 30, 676-693. [CrossRef]

42. Ismail, T.H.; Abdou, A.A.; Annis, R.M. Review of literature linking corporate performance to mergers and acquisitions. Rev. Financ. Account. Stud. 2011, 1, 89-104.

43. Krishnakumar, D.; Sethi, M. Methodologies used to determine mergers and acquisitions' performance. Acad. Account. Financ. Stud. J. 2012, 16, 75-91.

44. González-Torres, T.; Rodríguez-Sánchez, J.-L.; Pelechano-Barahona, E.; García-Muiña, F.E. A systematic review of research on sustainability in mergers and acquisitions. Sustainability 2020, 12, 513. [CrossRef]

45. Investopedia. Available online: https://www.investopedia.com/terms/s/sustainability.asp (accessed on 22 February 2021).

46. Elkington, J. Cannibals with Forks. The Triple Bottom Line of 21st Century; John Wiley \& Sons: Hoboken, NJ, USA, $1997 ;$ p. 73. 
47. Oprean-Stan, C.; Oncioiu, I.; Iuga, I.C.; Stan, S. Impact of Sustainability Reporting and Inadequate Management of ESG Factors on Corporate Performance and Sustainable Growth. Sustainability 2020, 12, 8536. [CrossRef]

48. Kell, G.; The remarkable rise of ESG. Forbes. Available online: https://www.forbes.com/advisor/investing/esg-investing/ (accessed on 18 February 2021).

49. D'Aquila, J.M. The current state of sustainability reporting. CPA J. 2018, 88, 44-50.

50. Huber, B.; Comstock, M.; Polk, D.; Wardwell, L.L.P. ESG reports and ratings: What they are, why they matter. In Proceedings of the Harvard Law School Forum on Corporate Governance and Financial Regulation, Cambridge, MA, USA, 27 July 2017.

51. Mooij, S. The ESG rating and ranking industry; Vice or virtue in the adoption of responsible investment? In Vice or Virtue in the Adoption of Responsible Investment; Elsevier BV: Amsterdam, The Netherlands, 2017.

52. Novethic Research. Available online: https://www.novethic.com/fileadmin/user_upload/tx_ausynovethicetudes/pdf_ complets/2013_overview_ESG_rating_agencies.pdf (accessed on 16 February 2021).

53. American Council for Capital Formation (ACCF). Available online: https://accfcorpgov.org/wp-content/uploads/2018/07/ ACCF_RatingsESGReport.pdf (accessed on 18 February 2021).

54. Friede, G.; Busch, T.; Bassen, A. ESG and financial performance: Aggregated evidence from more than 2000 empirical studies. J. Sustain. Financ. Investig. 2015, 5, 210-233. [CrossRef]

55. Bititci, U.S.; Ackermann, F.; Ates, A.; Davies, J.; Garengo, P.; Gibb, S.; MacBryde, J.; Mackay, D.; Maguire, C.; Van Der Meer, R.; et al. Managerial processes: Business process that sustain performance. Int. J. Oper. Prod. Manag. 2011, 31, 851-891. [CrossRef]

56. Neely, A.; Gregory, M.; Platts, K. Performance measurement system design: A literature review and research agenda. Int. J. Oper. Prod. Manag. 1995, 15, 80-116. [CrossRef]

57. Neely, A. The performance measurement revolution: Why now and what next? Int. J. Oper. Prod. Manag. 1999, 19, 205-228. [CrossRef]

58. Neely, A.; Mills, J.; Platts, K.; Richards, H.; Gregory, M.; Bourne, M.; Kennerley, M. Performance measurement system design: Developing and testing a process-based approach. Int. J. Oper. Prod. Manag. 2000, 20, 1119-1145. [CrossRef]

59. Neely, A. The evolution of performance measurement research. Int. J. Oper. Prod. Manag. 2005, 25, 1264-1277. [CrossRef]

60. Beaver, W.H. Financial Ratios As Predictors of Failure. JSTOR 1966, 4, 71. [CrossRef]

61. Ohlson, J.A. Financial Ratios and the Probabilistic Prediction of Bankruptcy. JSTOR 1980, 18, 109. [CrossRef]

62. Brigham, E.F.; Houston, J.F. Fundamentals of Financial Management; Cengage Learning: Belmont, CA, USA, 2019.

63. Refinitiv. An Overview of Environmental, Social and Corporate Governance-ESG. Available online: https://www.refinitiv.com/ en/financial-data/company-data/esg-data (accessed on 10 February 2021).

64. Refinitiv Business Classification. Available online: https://www.refinitiv.com/content/dam/marketing/en_us/documents/ quick-reference-guides/trbc-business-classification-quick-guide.pdf (accessed on 1 February 2021).

65. Malhotra, N.K.; Dash, S. Marketing Research: An Applied Orientation; Pearson: Upper Saddle River, NJ, USA, 2016.

66. Evans, J.D. Straightforward Statistics for the Behavioral Sciences; Thomson Brooks/Cole Publishing, Co.: Boston, MA, USA, 1996.

67. Corporate Finance Institute. Financial Ratios. Available online: https://corporatefinanceinstitute.com/resources/knowledge/ finance/financial-ratios / (accessed on 15 March 2021).

68. Investopedia. Ratio Analysis. Available online: https://www.investopedia.com/terms/r/ratioanalysis.asp (accessed on 15 March 2021). 